\title{
BRINGING HUMAN RIGHTS HOME: THE CHALLENGE OF ENFORCING JUDICIAL RULINGS IN UKRAINE AND RUSSIA
}

\author{
Andrey Meleshevich, Ph.D ${ }^{*}$ and Carolyn Forstein ${ }^{* *}$
}

\begin{abstract}
The problem of systemic non-enforcement of judicial decisions, the Ukrainian government's failure to respond to a pilot judgment, and Russia's legislative reform offer important case studies for both rule of law development in the post-Soviet sphere and the efficacy of the European human rights system. This article looks at systemic non-enforcement both as a domestic and international challenge. It first examines Ukraine's history with the European Court of Human Rights and the response to the Ivanov $v$. Ukraine 1 pilot judgment. It unpacks the factors that are responsible for persistent non-enforcement and for preventing domestic reform. It then turns to Russia, and explores the European Court of Human Rights' pilot judgment in the case Burdov v. Russia (no. 2), ${ }^{2}$ the Russian response, and implementation of the subsequent reforms. Lastly, the article examines the significance and implications of these cases for the European human rights regime.
\end{abstract}

* Ph. D, Dean and Professor, School of Law National University of Kyiv-Mohyla Academy. Academy.

Fulbright Research Fellow, School of Law National University of Kyiv-Mohyla

$\dagger$ The authors and the Indiana International \& Comparative Law Review would especially like to thank Viktoriia Serediuk-Buz for her editing assistance.

This Article was completed and submitted to the The Indiana International \& Comparative Law Review prior to the beginning of the Maidan protests in late 2013 and the end of the Yanukovych presidency in February 2014. Although the ongoing events in Ukraine have significantly changed the political landscape, this Article offers insight into the systemic problems facing the Ukrainian judiciary and some of the interest groups and governance issues, including budgetary shortfalls that have stymied reform in the past. Effective judicial reform remains a major challenge and priority for the current government, which must address the issues discussed within this Article in seeking to meet the international standards for effective and impartial judicial redress. On numerous occasions newly-elected President Petro Poroshenko has confirmed that Ukraine has chosen the European vector for its political and economic development. Adherence to the principles of the rule of law including strict execution of both international and domestic court decisions would signify an important step towards European values and standards.

1. Ivanov v. Ukraine, 2009 Eur. Ct. H.R. 767, archived at http://perma.cc/Q8HM8WSG.

2. Burdov v. Russia (No. 2), 2009 Eur. Ct. H.R., archived at http://perma.cc/LK8AZHLR. 


\section{INTRODUCTION}

Over the past several years, ${ }^{3}$ Ukraine has garnered international attention concerning challenges to democratic consolidation, widespread corruption in the top echelons of government, and the high-profile trials of former government officials and opposition leaders. ${ }^{4}$

However, one of the most significant obstacles to the development of rule of law in Ukraine is not new: the failure to enforce domestic judgments is an enduring feature of the national legal system. Nina Karpacheva, the former Human Rights Ombudsman of Ukraine, estimated in her 2011 annual report that over 60 percent of all domestic court decisions and 98 percent of the decisions of the European Court of Human Rights against Ukraine had not been fully enforced. ${ }^{5}$ While several factors contribute to the development of rule of law, a system in which verdicts regularly go unenforced cannot be said to provide consistent, fair, or meaningful justice.

Article 6 of the Convention for the Protection of Human Rights and Fundamental Freedoms guarantees the right to "adequate and timely execution of legitimate judicial decisions." The failure to enforce a court decision violates an individual's right to a fair trial, which the European Court of Human Rights describes as a fundamental component of the rule of law, ${ }^{7}$ as well as the right to an effective remedy for the original violation found by the court.

Domestic and international observers, the Ukrainian government, and the Council of Europe have repeatedly acknowledged and discussed this systemic shortcoming. In several of its earliest judgments against Ukraine, delivered in 2004, the European Court of Human Rights found Ukraine guilty of violating article 6 of the European Convention due to the state's failure to effectively enforce domestic court decisions. ${ }^{8}$ Through the

3. The authors also thank Nazar Kulchytsky for his comments on a draft of this Article.

4. Oleksandr Sushko \& Olena Prystayko, Freedom House, Nations in Transit 2013, UKRAINE, archived at http://perma.cc/ZG4Z-AX3J.

5. Nina Karpacheva, Vystup Upovnovazhenoho Verkhovnoyi Rady Ukrayiny z prav lyudyny Niny Karpachovoyi pid chas predstavlennya Shchorichnoyi dopovidi pro stan dotrymannya ta zakhystu prav i svobod lyudyny v Ukrayini u Verkhovniy Radi Ukrayiny [Speech of the Human Rights Ombudsman of Ukraine Nina Karpachova Presenting the Annual Report on the State of Human Rights in Ukraine], OMBUDSMAN OF THE VERKHOVNA RADA OF UKRAINE FOR HUMAN RIGHTS, 18-19 (Feb. 7, 2012), archived at http://perma.cc/G6EW-M84R.

6. Andrey Meleshevich \& Anna Khvorostyankina, Ukraine, in THE EUROPEAN Convention on Human Rights and Fundamental Freedoms in Central and Eastern EUROPE 576 (Leonard Hammer \& Frank Emmert eds., 2012); Convention for the Protection of Human Rights and Fundamental Freedoms, 213 U.N.T.S. 221, art. 6.

7. Sunday Times v. United Kingdom, 30 Eur. Ct. H.R. (ser. A) $\S 55$ (1979).

8. E.g., Voytenko v. Ukraine, 2004 Eur. Ct. H.R., archived at http://perma.cc/FS6NK792; Zhovner v. Ukraine, 2004 Eur. Ct. H.R., archived at http://perma.cc/5V3N-MXUXı. 
beginning of 2012, the court issued 432 similar judgments against Ukraine. ${ }^{9}$ In 2009, the European Court of Human Rights issued a pilot judgment, which compelled the Ukrainian authorities to address non-enforcement on an institutional level and set a time period for a sufficient national response. ${ }^{10}$ This deadline passed in July of 2011. ${ }^{11}$ At the time of writing this Article, the Ukrainian government has not instituted any of the required domestic reforms, ${ }^{12}$ arguably making Ukraine the first state to ever fail to respond to a pilot judgment of the European Court of Human Rights.

The Council of Europe has identified non-enforcement of domestic judgments as a systemic, ongoing challenge not only in Ukraine but also in Russia, Moldova, and Romania. ${ }^{13}$ Nine months before applying the pilot judgment procedure against Ukraine for non-enforcement of domestic judgments, the European Court of Human Rights issued a pilot judgment against Russia concerning the same issue. ${ }^{14}$ In contrast to Ukraine, Russia, a country with its own thorny history of relations with the European Court of Human Rights, responded within the prescribed time period by passing federal legislation designed to tackle the issue. ${ }^{15}$

The problem of systemic non-enforcement of judicial decisions, the Ukrainian government's failure to respond to a pilot judgment, and Russia's legislative reform offer important case studies for both rule of law development in the post-Soviet sphere and the efficacy of the European human rights system. This Article looks at systemic non-enforcement both as a domestic and international challenge. It first examines Ukraine's history with the European Court of Human Rights and the response to the

9. Eur. Ct. Hum. Rts., Violation by Article AND by State 1959-2011 (2011), archived at http://perma.cc/Y5CT-CSLR. In addition to the 432 decisions concerning violations of the right to a fair trial, the European Court of Human Rights also issued 259 decisions in which it found Ukraine guilty of violating the right to a hearing within a reasonable period of time. Id.

10. Ivanov v. Ukraine, 2009 Eur. Ct. H.R., archived at http://perma.cc/Q8HM-8WSG.

11. Comm. of Ministers, Communication from the Registry of the European Court Concerning the Pilot Judgment Delivered in the Case of Yuriy Nikolayevich Ivanov against Ukraine 1 (2011).

12. Eur. Ct. Hum. Rts., Press Unit, Pilot Judgments: Factsheet 3-4 (2013), archived at http://perma.cc/YM7F-FBPG.

13. Eur. Parl. Ass., States with Major Structural/Systemic Problems Before the European Court of Human Rights: Statistics, Doc. AS/Jur/Inf (2011) 05 rev 2 (2011), archived at http://perma.cc/Q4HA-TGL5.

14. Burdov v. Russia (No. 2), 2009 Eur. Ct. H.R., archived at http://perma.cc/LK8AZHLR.

15. Council of Eur., Comm. of Ministers, Interim Resolution, Execution of the Judgment of the European Court of Human Rights Burdov No. 2 Against the Russian Federation Regarding Failure or Serious Delay in Abiding by Final Domestic Judicial Decisions Delivered Against the State and its Entities as well as the Absence of an Effective Remedy, CM/ResDH (2011) 293 (2011), archived at http://perma.cc/4TMK-9ZWJ. 
Ivanov $v$. Ukraine pilot judgment. ${ }^{16}$ It unpacks the factors that are responsible for persistent non-enforcement and for preventing domestic reform. It then turns to Russia, and explores the court's pilot judgment in the case Burdov v. Russia (no. 2), ${ }^{17}$ the Russian response, and implementation of the subsequent reforms. Lastly, the Article examines the significance and implications of these cases for the European human rights regime.

\section{A HISTORY OF NON-ENFORCEMENT IN UKRAINE}

The non-enforcement of domestic judgments is an enduring problem in post-Soviet Ukraine, as reflected by Ukraine's record at the European Court of Human Rights. Ukraine acceded to the Council of Europe in 1995, ratified the European Convention on Human Rights in 1997, and received its first judgment from the European Court of Human Rights in $2001 .^{18}$ In 2004, the court issued a decision in Zhovner v. Ukraine, the first case concerning non-enforcement, and since then the number of applications presenting this issue has continued to grow. ${ }^{19}$ By 2010 , cases about the nonenforcement of domestic decisions comprised over 50 percent of all European Court of Human Rights judgments against Ukraine. ${ }^{20}$

The widespread nature of the issue has not gone unnoticed. The Committee of Ministers, the branch of the Council of Europe responsible for overseeing the execution of European Court of Human Rights judgments, monitored the Zhovner decision and subsequent similar rulings. A number of documents produced by the Committee of Ministers confirm that while the Ukrainian government is well aware of the problem of nonenforcement and ready to provide financial compensation to individual claimants at the European Court of Human Rights, it has not made effective efforts at systemic reform.

The first serious international assessment of systemic nonenforcement of judicial decisions in Ukraine was a June 2007 memorandum prepared by the Department for Enforcement of Judgments of the European

16. Ivanov v. Ukraine, 2009 Eur. Ct. H.R. 767, archived at http://perma.cc/Q8HM8WSG.

17. Burdov v. Russia (No. 2), 2009 Eur. Ct. H.R.

18. Press Unit, Pilot Judgments: Factsheet, supra note 12 , at 1.

19. Zhovner v. Ukraine, 2004 Eur. Ct. H.R., archived at http://perma.cc/5V3N-MXUX।. The court ruled on a handful of Ukrainian cases between 2001-2003, and the Zhovner judgment was only the seventeenth judgment regarding Ukraine. See Council of Europe, Judgment and Decisions, European Court of Human Rights (last visited March 8, 2014), http://www.echr.coe.int/Pages/home.aspx?p=caselaw\&c=.

20. Christos Pourgourides, Council of Eur., Implementation of Judgments of the European Court of Human Rights 7th Report, Doc. AS/Jur (2010) 36, ๆ 153 (2010) [hereinafter Pourgourides, 7th Report], archived at http://perma.cc/QC86-MFN5. 
Court of Human Rights at the Committee of Ministers. The memorandum identified five key underlying factors: a lack of financing in the state budget to enforce judgments against the state or state-owned companies; the complexity of the legal rules for seizure of state-owned accounts; a lack of regulations ensuring compensation for delayed enforcement; a lack of liability for the officials tasked with enforcement; and the inefficiency of the Ukrainian bailiffs' service. ${ }^{21}$ The document also specifically praised the National Action Plan for Ensuring Due Enforcement of Courts' Decisions, which was approved by Decree of the President of Ukraine on June 27, 2006, and proposed a number of measures to "increase the efficiency of the state enforcement service and improve the procedure for compulsory enforcement." 22

In March of 2008, the Committee of Ministers noted positively that Ukraine had developed three draft laws, which sought to end a prohibition on the forced sale of state-owned assets and increase the efficiency of enforcement procedures, but recorded that "little progress has been made so far in resolving the structural problem of non-execution of domestic judicial decisions." 23 A subsequent Interim Resolution in 2009 noted that none of the draft laws had been adopted and "deplore[d]" that "the Ukrainian authorities have continuously failed to give priority to finding effective solutions." 24 While both the Committee of Ministers and the Ukrainian government acknowledged that non-enforcement was a critical and complicated issue demanding reform in multiple sectors, the government made no tangible progress at addressing non-enforcement through the end of 2009. This persistent inaction set the stage for a pilot judgment against Ukraine.

In recent years, a mass of identical applications have accumulated at the European Court of Human Rights, primarily concerning article $6 .{ }^{25}$ The

21. Comm. of Ministers, Non-Enforcement of Domestic Judicial Decisions in Ukraine: General Measures to Comply with the European Court's Judgments, CM/Inf/DH (2007) 30, 6 (2007) revised.

22. Ukaz Prezydenta Ukrayiny №587/2006 "Pro Natsionalnyi plan dii iz zabezpechennya nalezhnoho vykonannya rishen sudiv" [Decree of the President of Ukraine №587/2006 on the National Action Plan for Ensuring Due Enforcement of Courts Decisions], June 27, 2006, archived at http://perma.cc/4LMF-D2JM.

23. Comm. of Ministers, Final Resolution on the Execution of the Judgements of the European Court of Human Rights in 232 Cases Against Ukraine Relative to the Failure or Serious Delay in Abiding by Final Domestic Judicial Decisions Delivered Against the State and its Entities as Well as the Absence of an Effective Remedy, CM/ResDH (2008) 1, I 32 (2008).

24. Comm. of Ministers, Interim Resolution Execution of the Judgments of the European Court of Human Rights in 324 Cases Against Ukraine Concerning the Failure or Serious Delay in Abiding by Final Domestic Courts' Decisions Delivered Against the State and its Entities as Well as the Absence of an Effective Remedy, CM/ResDH (2009) 1591, I 13 (2009).

25. Christos Pourgourides, Council of Eur., Report on Implementation of Judgments of 
vast majority of admissible applications are repetitive of earlier cases, revealing systemic violations, and stemming primarily from Russia, Ukraine, Turkey, Italy, Poland, and Romania. ${ }^{26}$ The resulting backlog of cases has caused much concern, and consequently, detailed debate within the Council of Europe concerning the structure and future of the European Court of Human Rights. ${ }^{27}$

The pilot judgment procedure is a relatively new function of the court, used for the first time in 2004 in the case of Broniowski v. Poland. ${ }^{28}$ The procedure is a means to support reform at the national level to eliminate the causes of repeated violations of the European Convention, thereby ameliorating two significant problems. By compelling member states to address their systemic shortcomings, the court ensures the effective protection of the rights guaranteed by the Convention while fully complying with the principle of subsidiarity. ${ }^{29}$ Additionally, the pilot judgment procedure reduces the number of repetitive applications to the court, which have become a serious threat to the efficacy of the court.

The central idea of the pilot mechanism is "that where there are a large number of applications concerning the same problem, applicants will obtain redress more speedily if an effective remedy is established at national level than if their cases are processed on an individual basis in Strasbourg. ${ }^{30}$ In a pilot judgment, the European Court of Human Rights goes beyond calling for general measures, by specifically identifying "the dysfunction under national law that is at the root of the violation," and proposing steps to the responsible state government to remedy the problem and resolve similar pending cases. ${ }^{31}$ Another unique feature of the pilot

the European Court of Human Rights, Doc. 12455, 38 (2010), archived at http://perma.cc/9V5P-R49Z.

26. Eur. Parl. Ass., supra note 13, at 4.

27. Three high level conferences took place in 2010, 2011, and 2012 at Interlaken, Izmir, and Brighton, respectively, regarding the future of the European Court of Human Rights. Each conference included official representatives from all member states and produced a declaration, which can be accessed via the European Court's website at http://www.echr.coe.int/ECHR/EN/Header/The+Court/Reform+of+the+Court/Conferences/, archived at http://perma.cc/64DZ-ZG3.

28. Press Unit, Pilot Judgments: Factsheet, supra note 12, at 1; Broniowski v. Poland, 2004 Eur. Ct. H.R. 307, archived at http://perma.cc/SD8K-M4BR.

29. According to the European Court, the principle of subsidiarity is one of the most fundamental principles for the whole Convention system and might have several somewhat different meanings; "however, in the specific context of the European Court of Human Rights, it means that the task of ensuring respect for the rights enshrined in the Convention lies first and foremost with the authorities in the Contracting States rather than with the Court. The Court can and should intervene only where the domestic authorities fail in that task." Eur. Ct. Hum. Rts., Interlaken Follow-Up, Principle of Subsidiarity (2010), archived at http://perma.cc/W2YL-32JX.

30. Eur. Ct. Hum. Rts., The Pilot-Judgment Procedure: Information Note Issued By the Registrar, 6 (2009), archived at http://perma.cc/3RW9-VRQL.

31. Id. at 3 . 
judgment procedure is that the court has the option of freezing all of the related pending admissible applications to the European Court of Human Rights for a set period of time, giving a government the opportunity and incentive to resolve them on the domestic level. ${ }^{32}$

\section{A PILOT JUdGMENT For UKRAINE}

The case of Yuriy Nikolayevich Ivanov v. Ukraine ${ }^{33}$ was the first pilot judgment against Ukraine and exemplifies the commonplace challenge of enforcing a domestic judgment in Ukraine. Yuriy Ivanov served in the Ukrainian army and retired in $2000 .{ }^{34}$ Upon his retirement, Ivanov was entitled to one-time retirement payment and compensation for his uniform, but did not receive either. ${ }^{35}$ Ivanov took his case to court, and in August 2001 a regional military court found in his favor, ordering his military unit to pay him the retirement sum, uniform compensation, and court fees, all of which together totaled 4,012.86 hryvnia, or approximately EUR 800 at the time. ${ }^{36}$ Over the next several years, Ivanov pursued his case in multiple courts in an effort to have this decision enforced. ${ }^{37}$ At an unspecified point, Ivanov received the 2,515.50 hryvnia owed to him for the retirement lump sum, but nothing towards the awards for his uniform and court fees. ${ }^{38}$ In January 2002, bailiffs informed Ivanov that they had frozen the bank accounts of the debtor, his former military unit, but that "no funds had been found in those accounts." 39 The following November, Ivanov received a letter from the Ukrainian Ministry of Defense explaining that he was not entitled to compensation for his uniform as there were "no budgetary allocations for such payments." ${ }^{, 4}$ In April 2004, more than two and a half years after the original judgment was issued against the military unit, the bailiffs informed Ivanov by letter that the unit still had no money and that "forced sale of assets belonging to military units was prohibited by the law," and thus that they had no means of enforcing the judgment. ${ }^{41}$

Following the bailiffs' response in January 2002, Ivanov lodged a separate complaint in a district court about the lack of action. ${ }^{42}$ In December 2002, that court ruled that the bailiffs "had not taken the necessary measures" and ordered them to "identify and freeze the bank accounts of

\footnotetext{
32. $I d$. at $\uparrow 5$.

33. Ivanov v. Ukraine, 2009 Eur. Ct. H.R., archived at http://perma.cc/Q8HM-8WSG.

34. Ivanov 98.

35. Ivanov 8 .

36. Ivanov 99.

37. Ivanov $\uparrow \uparrow 16-19$.

38. Ivanov $₫ 10$.

39. Ivanov $₫ 11$.

40. Ivanov 12.

41. Ivanov $\mathbb{} 14$.

42. Ivanov 16.
} 
the debtor military unit in order to seize the money available in those accounts." ${ }^{43}$ According to Ivanov, the bailiffs did not comply with this ruling, and in May of 2003 he lodged yet another claim in the same district court against the bailiffs seeking both compensatory and non-pecuniary damages. ${ }^{44}$ Finding that the August 2001 judgement was still unenforced "through the fault of the bailiffs," the district court in July 2003 awarded Ivanov 1,500.36 hryvnia in pecuniary damages and another 1,000 hryvnia in non-pecuniary damages. ${ }^{45}$ This judgment, in turn, was similarly not executed. By 2009, when the European Court of Human Rights ruled on Ivanov's case, both the remainder of the initial judgment of 2001 and the 2003 judgment against the bailiffs' remained unenforced, amounting to a delay of over seven years. ${ }^{46}$

The near-decade Ivanov spent pursuing what should have been a routine payment prescribed by Ukrainian law is emblematic of the obstacles facing Ukrainian citizens in interacting with the national legal system. The European Court of Human Rights found violations of Ivanov's rights under article 6 section 1 , article 13, and article 1 of protocol 1 for the nonenforcement of both the 2001 and 2003 judgments. ${ }^{47}$ The court noted that in similar cases against Ukraine it had repeatedly found violations of article 6 section 1, which guarantees the right to a fair trial, including enforcement, and article 1 of protocol 1 , which protects property rights. ${ }^{48}$ While acknowledging that the delays in enforcement had numerous causes, "including the lack of budgetary funds, omissions on the part of the bailiffs, and shortcomings in the national legislation," the court stressed that "those factors were not outside the control of the authorities," and that the state was responsible for the violations. ${ }^{49}$

Regarding article 13, which protects the right to an effective remedy, the European Court of Human Rights referenced both past cases against Ukraine, and the pilot judgment issued against Russia nine months earlier in Burdov (2) v. Russia, which also concerned non-enforcement. ${ }^{50}$ Citing Burdov, the court noted that "the burden to comply" with a domestic judgment regarding enforcement "lies primarily with the State authorities." ${ }^{, 51}$ The court also recalled the Voytenko v. Ukraine case, in which another veteran seeking compensation from his former military unit faced the same obstacles to enforcement as Ivanov. In Voytenko, the court

\footnotetext{
43. Ivanov 916.

44. Ivanov 17.

45. Ivanov 918.

46. Ivanov 955.

47. Ivanov 9 ๆ $57,69-70$.

48. Ivanov 956.

49. Ivanov $9955-58$.

50. Ivanov $9 \uparrow 65-67$.

51. 2009 Eur. Ct. H.R.
} 
found that the enforcement of judgments against a government institution "can only be carried out if the State foresees and makes provision for the appropriate expenditures in the State Budget of Ukraine," and thus that enforcement of judgments is "prevented precisely because of the lack of legislative measures, rather than by a bailiff's misconduct." 52 Neither individual citizens nor bailiffs or judges have any ability to enforce court decisions concerning a monetary award if the necessary funds are not already in place.

The facts of the Ivanov case clearly demonstrated that nonenforcement was a longstanding issue with roots in several aspects of the Ukrainian legal, judicial, and political systems. After discussing the individual merits of the case, the European Court of Human Rights decided to apply the pilot judgment procedure for the first time against Ukraine, citing "the recurrent and persistent nature of the underlying problems, the large number of people affected by them in Ukraine and the urgent need to grant them speedy and appropriate redress at domestic level., ${ }^{, 53}$

In contrast to past decisions and general measures, the pilot judgment set out specific conditions and deadlines. The court granted Ukraine one year from the date the decision became final to introduce "an effective domestic remedy or combination of such remedies capable of securing adequate and sufficient redress for the non-enforcement or delayed enforcement of domestic decisions." "54 The court decided to adjourn proceedings for the approximately 1,400 pending applications concerning similar issues for the course of this year, during which time the Ukrainian government was encouraged to resolve these cases through individual settlements or the implementation of a new domestic judicial mechanism. ${ }^{55}$ Any new applications concerning the same issues that arose during the year would also be adjourned, and the applicants notified. ${ }^{56}$ If Ukraine failed to take action and set up a new functional remedy or to resolve the former group of cases, the court would resume consideration of all pending applications, including those received after the pilot judgment became final. $^{57}$

\section{UKRAINE’S RESPONSE}

The Ukrainian response to the pilot judgment has been minimal. The Ivanov judgment was issued on October 15, 2009, and became final on

52. Voytenko v. Ukraine, 2004 Eur. Ct. H.R. ๆ 30, archived at http://perma.cc/FS6NK792.

53. Ivanov $₫ 81$.

54. Ivanov at $27-28$ ( $\$ 5$ of verdict).

55. Ivanov $\uparrow \uparrow 86,98-99$.

56. Ivanov 997.

57. Ivanov $\uparrow 100$. 
January $15,2010 .{ }^{58}$ In an interim resolution assessing Ukraine's progress in November 2010, the Committee of Ministers evaluated the execution of the Ivanov pilot judgment and 386 other decisions against Ukraine concerning non-enforcement of domestic decisions and the lack of an effective remedy. ${ }^{59}$ The Committee of Ministers reported that the Ukrainian authorities had informed them of the preparation of a draft law entitled $O n$ Enforcement of the Court Decisions for which the State is Responsible, but had not provided either details of its content or a timetable for its passage. ${ }^{60}$ The resolution also noted that Ukraine had made little progress in settling the pending individual cases. ${ }^{61}$ Christos Pourgourides, the Chair of the Committee on Legal Affairs and Human Rights of the Parliamentary Assembly of the Council of Europe (PACE), assessed the Ukrainian response to Ivanov in a November 2010 report, stating that "this issue, to my consternation, does not appear to be a priority for the authorities, notwithstanding the clear wording of the Court's pilot judgment." 62

In December 2010, a month before the initial deadline was set to expire, the Ukrainian government requested a 12-month extension. ${ }^{63}$ In response, the European Court of Human Rights granted Ukraine a 6-month extension through July 15, 2011, but noted that non-enforcement "had not improved in the year since the judgment became final," and that the reported draft law on enforcement had not been passed. ${ }^{64}$ While some of the individual cases had been settled, approximately 1,100 cases remained unresolved, and the court planned to process another 450 related cases that had been received after the Ivanov judgment became final. ${ }^{65}$

In June, the Government Agent of Ukraine before the European Court of Human Rights, Valeria Lutkovska, reported that a draft law entitled On Guarantees of the State Concerning Execution of Court Decisions, which "address[ed] problems identified by the Court's pilot judgment and provid[ed] a domestic remedy," had been introduced in the Verkhovna Rada and was awaiting a first reading. ${ }^{66}$ This statement did not correspond

58. Ivanov (at the top of the judgment).

59. Comm. of Ministers, Interim Resolution Execution of the Pilot Judgment of the European Court of Human Rights in the Case Yuriy Nikolayevich Ivanov against Ukraine and of 386 Cases against Ukraine Concerning the Failure or Serious Delay in Abiding by Final Domestic Courts' Decisions Delivered against the State and its Entities as well as the Absence of an Effective Remedy, CM/ResDH (2010) 222, (2010).

60. Id. ๆ⿻ 9-10.

61. Id. ๆ 11 .

62. Pourgourides, 7th Report, supra note 20, 1158.

63. Comm. of Ministers, Communication from the Registry of the European Court concerning the Pilot Judgment Delivered in the Case of Yuriy Nikolayevich Ivanov against Ukraine, (Application No. 40450/04), DH-DD (2011) 54E, 1 (2011).

64. Id.

65. Id. at 1-2.

66. Comm. of Ministers, Communication from Ukraine in the case of Yuriy 
with actual events, as a bill with this name was only introduced in the Rada in September of 2011.

The first version of this draft law had the slightly different title $O n$ Guarantees of the State Concerning Execution of Decisions of the Court (No. 7562) and was reportedly introduced in the Verkhovna Rada, according to the Rada's official website, on January 14, 2011, one day before the original deadline set by the pilot judgment expired. ${ }^{67}$ However, this bill was never introduced for debate and, on September 6, 2011, was removed from the agenda of the Rada. ${ }^{68}$ The second version, which was de jure a new draft law, entitled On Guarantees of the State Concerning Execution of Court Decisions (No. 9127) was introduced in parliament on September 8, 2011, and adopted at first reading the following day. ${ }^{69}$

In July 2011, the government requested another six-month extension. ${ }^{70}$ This time, the court rejected the extension request, noting that there had been no improvement in enforcement over the past year and a half. ${ }^{71}$ The court emphasized that approximately 1,000 of the frozen cases remained unsettled and pointed to the Committee of Ministers as the best body to assist Ukraine in implementing legislative and administrative reforms. $^{72}$

In correspondence with the Committee of Ministers, the Ukrainian government repeatedly pointed to the proposed draft law as a potential solution. In a September 2011, communication to the Department for the Execution of Judgments of the European Court of Human Rights, Valeria Lutkovska described how the law provides a "new procedure for execution" of court decisions as well as a "solution of the problem concerning the outstanding debt that is to be paid" by amending multiple laws regulating social benefits and other components of the State budget. ${ }^{73}$ The Committee

Nikolayevich Ivanov (Application No. 40450/04) and the Zhovner group of cases (Application No. 56848/00) against Ukraine, DH-DD (2011) 433E (2011).

67. Proekt zakony pro harantii derzhavy shchodo vykonannya rishen' sudu [Draft Law on Guarantees of the State Concerning the Enforcement of Decisions of the Court], KARTKA ZAKONOPROYEKTU [RECORD OF THE DRAFT LAW] (2011) [hereinafter Draft Law No. 7562], available at http://w1.c1.rada.gov.ua/pls/zweb2/webproc4_1?pf3511=39454 (last visited May 17, 2014).

68. Id.

69. Proekt zakony pro harantyi derzhavy shchodo vykonannya sudovykh rishen' [Draft Law On Guarantees of the State Concerning the Enforcement of Court Decisions], KARTKA ZAKONOPROYEKTU [RECORD OF THE DRAFT LAw], (2011) [hereinafter Draft Law No. 9127], available at http://w1.c1.rada.gov.ua/pls/zweb2/webproc4_1?pf3511=41092 (last visited May 17, 2014).

70. Comm. of Ministers, Communication from the Registry of the European Court Concerning the Judgment Delivered in the Case of Yuriy Nikolayevich Ivanov against Ukraine (Application No. 40450/04), DH-DD (2011) 757E (2011), archived at http://perma.cc/3DNC-4FD3.

71. Id.

72. Id.

73. Comm. of Ministers, Communication from Ukraine Concerning the Cases of Yuriy 
of Ministers and various officials from the Council of Europe called on Ukraine to pass the proposed draft law without delay. ${ }^{74}$ However, the law, which includes a provision authorizing the Cabinet of Ministers to change the amount of the social benefits paid in a given year depending on the size of the annual budget, has faced strong opposition from civil society organizations and social groups. ${ }^{75}$

In December of 2011, the Committee of Ministers passed an interim resolution conveying its regret that Ukraine had yet to fully execute the pilot judgment and stating that this failure "creates a serious threat to the effectiveness of the Convention," Rights. The Committee of Ministers again stressed the need for the Ukrainian authorities to resolve the pending individual cases, and to "urgently" provide an alternative remedy if the draft law would not be passed. $^{77}$ In late February 2012, the European Court of Human Rights examined the state of implementation of the Ivanov judgment. Noting that Ukraine had "not adopted the required general measures to tackle the issues of non-enforcement at the domestic level," the court decided to unfreeze and resume consideration of the similar cases pending at the court, which by February numbered approximately $2,500 .^{78}$ The court found that the Ukrainian authorities had not only failed to implement reforms that would prevent future violations, but also failed to settle about 700 of the individual cases which the court had directly communicated to the Ukrainian Government. ${ }^{79}$ The Committee of Ministers released another decision on March 12, which again emphasized that the pilot judgment had not been implemented in full and called upon the Ukrainian authorities to urgently take steps towards its execution, including making necessary changes to the draft law On Guarantees of the State Concerning Execution of Court Decisions (No. 9127) and providing information on the timing of its passage. $^{80}$

Nikolayevich Ivanov against Ukraine (Application No. 40450/04) and Kharchenko against Ukraine (Application No. 40107/02), DH-DD (2011) 705E (2011).

74. Comm. of Ministers, Interim Resolution Execution of the Pilot Judgment of the European Court of Human Rights Yuriy Nikolayevich Ivanov against Ukraine and of 386 Cases against Ukraine Concerning the Failure or Serious Delay in Abiding by Final Domestic Courts' Decisions Delivered against the State and its Entities as Well as the Absence of an Effective Remedy, CM/ResDH (2011) 184 (2011), archived at http://perma.cc/964R-8VH6.

75. See infra Sections VI and VIII.

76. Comm. of Ministers, Decision Cases No. 24 - Yuri Nikolaevich and Zhovner Group against Ukraine, CM/Del/Dec (2011) 1128/24 (2011).

77. Id.

78. Press Release, ECHR 086, Eur. Ct. of Hum. Rts., Court Decides to Resume Examination of Applications Concerning Non-Enforcement of Domestic Decisions in Ukraine (Feb. 29, 2012).

79. Id.

80. Comm. of Ministers, Decision Cases No. 24 - Yuri Nikolaevich and Zhovner Group against Ukraine, CM/Del/Dec (2012) 1136/24 (2012). 
Finally, on June 5, the Verkhovna Rada adopted draft law No. 9127 in its final reading, and on June 22, the President of Ukraine signed the bill into law. ${ }^{81}$ Law of Ukraine No. 4901-VI On Guarantees of the State Concerning Execution of Court Decisions entered into force on January 1, $2013 .^{82}$ Our analysis of Law No. $4901-$ VI below ${ }^{83}$ shows that the law is unlikely to change the dynamics of enforcement of court judgments in Ukraine in the near future.

\section{UNPACKING SYSTEMIC NON-ENFORCEMENT}

The reasons for the systemic non-enforcement of Ukrainian judicial decisions and the decisions of the European Court of Human Rights against Ukraine fall into two camps: the social, economic, financial, and administrative norms in modern Ukraine; and the lack of will among the relevant state actors. International and Ukrainian experts acknowledge that non-enforcement of domestic judgments is a systemic, enduring problem with roots in multiple sectors, and demands complex and far-reaching reforms. ${ }^{84}$ At the same time, the absence of such reforms, in combination with the Ukrainian government's ongoing failure to settle the pending individual cases at the European Court of Human Rights and inadequate response to the pilot judgment reflects a clear lack of political will.

Practitioners and scholars have identified several factors that influence governments' responses to pilot judgments. One of the most important components is a state's capacity for reform. The issues concerned in pilot judgments are by definition systemic problems, and shortcomings in national responses are due in part to the complexity of effectively addressing these weaknesses. Scholars Philip Leach, Helen Hardman, Svetlana Stephenson, and Brad K. Blitz posit that "a state's non-compliance with a pilot judgment may be the result of 'voluntary' resistance (where there is a conscious decision not to execute the judgment) or 'involuntary' resistance (where there is political will to implement the judgment, but the state is simply not able to bring about the requisite changes)." ${ }^{" 85}$ They

81. Zakon Ukrayiny pro harantii derzhavy shchodo vykonannya sudovyx rishen' [Law of Ukraine on Guarantees of the State Concerning the Enforcement of Court Decisions], OfitsiYnYy VisnYk UKRAYINY [OfFicial Journal of Ukraine], 2012 No. 49, Item 1919, [hereinafter Law No. 4901-VI], archived at http://perma.cc/HYZ9-5P7Z.

82. Id.

83. See infra Section VIII.

84. See, e.g., Ihor Bilyk, Garantii derzhavy shchodo vykonannya sudovykh rishen' [State Guarantees regarding Execution of Court Decisions], Soter Law Firm, August 2, 2012, archived at http://perma.cc/Z33E-MF52; Nadia Dobryanska \& Andrey Meleshevich, The Rule of Law and the Case Law of the European Court of Human Rights on the Execution of Court Decisions in Ukraine, 77 NAT'L U. OF KyiV-Mohyla ACAD. ReV., Legal Stud. 37 , 37-43 (2008).

85. Philip Leach et al., Responding to Systemic Human Rights Violations: An 
observe that involuntary resistance has thus far been more common than voluntary resistance. With this in mind, they suggest that the pilot judgment procedure may be more effective for cases regarding specific issues - such as Broniowski v. Poland, which was brought by a group of people who had not received compensation for property lost in World War II-than for endemic problems like non-enforcement. ${ }^{86}$

In cases of voluntary resistance, or absent political will to reform, both political and institutional conditions play a role. National authorities may be particularly reluctant to cooperate with the European Court of Human Rights "if the alleged violation is a politically sensitive one or one that may set the state apart as one that grossly violates human rights." $\$ 77$ Thus, states' responses may depend in part on "the estimation of the national authorities as to the political and economic advantage in cooperation with the Court." ${ }^{88}$ Ongoing supervision of the execution of the judgment by the Committee of Ministers is particularly important, as it may be "sufficiently unpleasant for a minister to have to explain and justify the failings of the national authorities, to provide a clear incentive" to support legislative or political reform. ${ }^{89}$ A pilot judgment can serve as a catalyst for national-level reform, by drawing international attention to a problematic category of cases and thereby placing pressure on national authorities. ${ }^{90}$

Much also depends on the commitment and level of knowledge of the professionals working in the government agencies responsible for interaction with the European Court of Human Rights. The individuals working in the Government Agent's office, parliament, the judiciary, other government ministries, civil society and the media, and the extent of their "awareness and in-depth understanding of the European Convention," are critical in determining the national response. ${ }^{91}$ Christos Pourgourides, the Chair of the Committee on Legal Affairs and Human Rights of PACE, argues that national parliaments, as democratically elected bodies "are uniquely placed to scrutinize the actions of government so as to ensure the swift and effective implementation of the Court judgments." 92 States "with

Analysis of 'Pilot Judgments' of the European Court of Human Rights AND their IMPACT AT NATIONAL LEVEL 178 (2010).

86. Id. at 177 .

87. Janneke Gerards, The Pilot Judgment Procedure Before the European Court of Human Rights as an Instrument for Dialogue, Constitutional Conversations 9-10 (2011).

88. Id. at 10 .

89. Id. at 16

90. Francoise Tulkens, A Typology of the Pilot-Judgment Procedure, 2 Crossroads: the Macedonian Foreign Pol'y J. 131 (2010). Judge Tulkens, the European Court of Human Rights judge from Belgium and current Vice-President of the Court, specifically cites the Olaru v. Moldova case an as example of a pilot judgment that compelled national authorities to act.

91. LEACH ET AL., supra note 85, at 179.

92. Pourgourides, 7th Report, supra note 20, 195. 
strong implementation records are frequently characterized by strong participation of parliamentary actors in the implementation process" of Strasbourg Court judgments." 93 In addition to the political inclinations of national leaders, changes in national parliaments and administrations as well as institutional knowledge, or the lack thereof, can have a significant influence on a state's response to the European Court of Human Rights.

Which factors explain Ukraine's failure to respond to the European Court of Human Rights? The following sections analyze the root causes of persistent non-enforcement in Ukraine and the structural and political aspects impeding reform. Unpacking the Ukrainian response to Ivanov demonstrates that the lack of reform stems from three factors: the specifics of the social, economic, and administrative institutions in modern Ukraine, the budgetary system, and the absence of political will.

\section{RESTRICTIONS ON THE FORCED SALE OF DEBTORS’ ASSETS}

One of the primary causes of the failure to enforce judicial decisions in Ukraine is the legislation governing the sale of state assets and protecting certain debtors from financial responsibility. Former Ombudsman Nina Karpacheva emphasizes that non-enforcement stems from "above all, the restrictions set forth in the procedure for the enforcement of the court's decisions on state-owned enterprises and utilities," 94 and stresses that the "state does not propose ways to ensure the rights of citizens in these cases." 95 In Ivanov, the failure to enforce the original court decision requiring Ivanov's military unit to pay his retirement sum and uniform compensation was connected to a moratorium on the forced sale of state assets. $^{96}$

In November of 2001, the Verkhovna Rada adopted the law On Introduction of a Moratorium on Forced Sale of Property, which, for the purpose of "ensuring the economic security of the state," prohibits the forced sale of property of state enterprises or any enterprises in which the State holds at least a $25 \%$ stake. $^{97}$ The moratorium was imposed

93. Pourgourides, 7th Report, supra note 20, 197.

94. Nina Karpacheva, The State of ObSERvance of the European Standards on Human Rights and Freedoms in Ukraine, Special Report of the Ukrainian PARLIAMENT COMMISSIONER FOR HumAN RightS 39 (2010), archived at http://perma.cc/KM8A-RP9U.

95. Nina Karpacheva, Shchorichna dopovid' Upovnovazhenoho Verkhovnoyi Rady Ukrayiny z prav ludyny pro stan dotrymannya ta zakhystu prav i svobod lyudyny v Ukrayini [Annual Report of the Ombudsman to the Verkhovna Rada of Ukraine on the State of Human Rights in Ukraine], OMBUDSMAN OF THE VERKHOVNA RADA OF UKRAINE FOR HUMAN RIGHTS 21 (2010), archived at http://perma.cc/SKS7-RQN3.

96. Yuriy Nikolayevich Ivanov v. Ukraine, 2009 Eur. Ct. H.R. \14.

97. Zakon Ukrayiny, Pro vvedennya moratoriyu na prymusovu realizatsiyu majna [Law of Ukraine on the Introduction of a Moratorium on the Forced Sale of Assets], VIDOMOSTI 
indefinitely ${ }^{98}$ and remains in effect at the time of writing of this article. In a case where such an enterprise does not have sufficient funds in its accounts to respond to a judgment - as was the case with the debtor military unit in Ivanov - neither the court nor the bailiffs have any means of enforcing the decision.

In 2003, forty-seven members of parliament brought a petition to the Constitutional Court of Ukraine arguing that the 2001 Law on Moratoriums made it practically "impossible for the State Execution Service to implement court decisions of a proprietary nature." 99 However, in its judgment on October 6, 2003, the Constitutional Court ruled that this law was constitutional. The Constitutional Court's decision raised eyebrows, as "this moratorium violate[d] at least two constitutional principles: the rule of law and equality of all forms of property."

A second protected sector is the energy and fuel industry. According to the 1999 Law of Ukraine On Enforcement Proceedings, any enforcement proceedings of court decisions must be suspended if the debtor is a fuel or energy enterprise seeking to resolve its debts through the procedure established in the Law of Ukraine On Measures to Ensure the Stable Operation of Enterprises of the Fuel and Energy Complex. ${ }^{101}$ According to the latter law, if a fuel or energy company wants to resolve its debts, it can register on a list of fuel and energy enterprises kept by the Ministry of Fuel and Energy, after which it is generally exempt from state debt collection procedures. ${ }^{102}$

The scope of companies included on the registry is wide. Nazar Kulchytsky, the Government Agent of Ukraine to the European Court of Human Rights, explains that the list includes "all companies, mines, all

VERKHOVNOI RADY UKRAINY [VVR] No. 10, Item 77 (2002), archived at http://perma.cc/H5AK-H53L.

98. Id.

99. Rishennya Konstytutsiynoho Sudu Ukrayiny u spravi za konstytutsiynym podannyam 47 narodnyx deputativ Ukrayiny shchodo vidpovidnosti Konstitutsyi Ukrayiny Zakonu Ukrayiny "Pro vvedennya moratoriyu na prymusovu realizatsiyu mayna" [Decision of the Constitutional Court of Ukraine in the Case of the Constitutional Petition of 47 People's Deputies of Ukraine Concerning the Conformity with the Constitution of Ukraine of the Law of Ukraine "On the Introduction of a Moratorium on the Forced Sale of Assets"], no.11-rp/2003, June 10, 2003, OfITSIYNYY VisNYK UKRAYINY [OFFICIAL JOURNAL OF UKRAINE], No. 25, Item 1217 (2003), archived at http://perma.cc/NN5J-BBZK, English summary archived at http://perma.cc/HQN8-GN3V.

100. Dobryanska \& Meleshevich, supra note 84, at 41.

101. Zakon Ukrayiny "Pro vykonavche provadzhennya" [Law of Ukraine on Enforcement Proceedings], Vidomosti Verkhovnoi RAdy UkRainy [VVR] No. 24, Item 207 (1999), archived at http://perma.cc/R9D3-CLEN.

102. Zakon Ukrayiny "Pro zakhody, spryamovani na zabezpechennya staloho funktsionuvannya pidpryemstv palyvno-enerhetychnoho kompleksu" [Law of Ukraine on Measures to Ensure the Sustainable Operation of Enterprises of the Fuel and Energy Complex], Vidomosti Verkhovnoi Rady Ukrainy [VVR] No. 33, Item 430 (2005), archived at $\mathrm{http}: / /$ perma.cc/NSN3-FZE9. 
energy sectors or sectors related to this, and even entities which cooperate with such enterprises." 103 Enterprises included on the registry "could be absolutely private, but the state's bailiffs cannot do anything to execute judgments." ${ }^{104}$ The law on the fuel and energy complex, which seeks to protect these sectors because of their importance to the national economy, makes it legally impossible for a citizen to recoup arrears or other debts from an energy company, even with a court judgment. ${ }^{105}$ Some experts believe that this legislation was forced through by the owners of energy and fuel companies in their own personal interest, and violates the Constitution by effectively placing the fuel and energy complex outside the reach of the law. ${ }^{106}$

One example, described by Ombudsman Nina Karpacheva, provides insight into the extent of the debt of the fuel and energy complex. In 2010, the energy company Donetskoblenergo had an outstanding debt of over 800 million hryvnia - around 80 million euro-out "because Donetskoblenergo [was] an enterprise of the fuel and energy sector, the enforcement proceedings of court judgments [were] suspended."107 Another exception regards companies with property in the Chernobyl exclusion zone, as Ukrainian law prohibits the sale of property in the exclusion zone without specific government permission. ${ }^{108}$ Several former employees of Atomspetsbud, a state-owned construction company that worked in the Chernobyl exclusion zone after the nuclear accident, have brought and won cases at the European Court of Human Rights concerning the failure to enforce judgments of Ukrainian courts. ${ }^{109}$ The Ukrainian Helsinski Human Rights Union sums up the situation thusly: "When individuals owe money any property can be taken away in lieu. When the debtor is a State-owned

103. Interview by Carolyn Forstein with Nazar Kulchytsky, Government Agent of Ukraine to the European Court of Human Rights, in Kyiv, Ukr. (Feb. 3, 2012).

104. Id.

105. Mykhailo Honchar \& Maksym Alinov, Energy Debt: Cancellation of (Non) Responsibility, WEEKLY MIRROR (Kyiv), May 27, 2011, at 19, archived at http://perma.cc/K7GD-UFM2.

106. See, e.g. Anton Kutz, Untouchable Cast, or Fuel and Energy Enterprises, LeGAL WeEKLY (Kyiv), Jan. 26 - Feb. 1, 2010, at 4 archived at http://perma.cc/K824-TJ75; see also Honchar \& Alinov, supra note 105.

107. Karpacheva, supra note 95, at 22.

108. Zakon Ukrayiny "Pro pravovyy rezhym terytorii, shcho zaznala radioaktyvnoho zabrudnennya vnaslidok chornobyl'skoyi katastrofy" [Law of Ukraine on the Legal Status of the Territory of Radioactive Contamination Resulting from the Chornobyl Catastrophe], VIDOMOSTI VERKHOVNOI RADY URSR [VVR] 1991 No. 16, Item 198, archived at http://perma.cc/6YT2-8X29.

109. Mykhaylenky and Others v. Ukraine, 2004 Eur. Ct. H.R. 153; Derkach and Palek v. Ukraine, 2004 Eur. Ct. H.R., archived at http://perma.cc/5C7E-LSP8; Gaponenko v. Ukraine, 2006 Eur. Ct. H.R., archived at http://perma.cc/V45V-YPER; Ishchenko and Others v. Ukraine, 2005 Eur. Ct. H.R., archived at http://perma.cc/R2WN-CVQB; Sharenok v. Ukraine, 2005 Eur. Ct. H.R., archived at http://perma.cc/MSD2-9TLS. 
enterprise, it is virtually impossible to recoup any debt." $" 110$

The European Court of Human Rights has made it clear through its case law on non-enforcement that a state enterprise's lack of funds does not excuse it from the responsibility to respond to a court judgment. ${ }^{111}$ As the existing Ukrainian law makes it impossible to force entities to sell their assets, the European Court of Human Rights stressed that the state should bear responsibility for these debts. ${ }^{12}$ While the state budget includes a specific allocation for the enforcement of judgments of the court, it does not currently designate any funding for the enforcement of domestic decisions in which the financial liability falls on the state. ${ }^{113}$

The Ukrainian authorities have previously discussed legislative efforts aimed at resolving these legal issues. In several of the communications between the Ukrainian government and Committee of Ministers prior to the pilot judgment, as described in the previous section, the government reported developing draft laws removing the moratorium on the forced sale of state assets, but to date it remains in place. ${ }^{114}$ On December 4, 2007, draft law No. 1105 On Making Amendments to the Law of Ukraine 'On Restoring a Debtor's Solvency or Declaring his Bankruptcy' (on the order of priority of claims for satisfaction for salary arrears) was introduced in the Verkhovna Rada seeking to change the law suspending execution in the event of bankruptcy or liquidation procedures. ${ }^{115}$ However, shortly after Viktor Yanukovych claimed victory in Ukraine's 2010 presidential election, the newly-formed pro-presidential majority in the Rada voted this bill down on May 13, 2010, and to date "the problem remains unsolved."116

On February 11, 2010, the outgoing Cabinet of Ministers under Prime Minister Yulia Tymoshenko approved Resolution 222-p, which laid out a plan to address the systemic issues causing widespread non-enforcement. ${ }^{117}$

110. Maxim Shcherbatyuk \& Volodymyr Yavorsky, UHHRU: No Optimism Over New Draft Law on State Guarantees Regarding Enforcement of Court Rulings, UKRAINIAN HELSINKI HUMAN Rights UNION (May 10, 2011), archived at http://perma.cc/BA7E-RHTJ.

111. Shmalko v. Ukraine, 2004 Eur. Ct. H.R. 9ף 44, 57, archived at http://perma.cc/D4GN-SWZV.

112. Shmalko $19143-46$.

113. Shcherbatyuk \& Yavorsky, supra note 110.

114. See Draft Law No. 9127, supra note 69.

115. Property Rights, in Human Rights in Ukraine 2009-2010, Human Rights ORgANIZATIONS REPORT 234, 244 (Yevhen Zakharov, ed., 2011), archived at http://perma.cc/9MFR-Q5NH.

116. Id.

117. Kabinet Ministriv Ukrayiny Rozporyadzhennya 222-p "Pro zatverdzhennya planu pershocherhovykh zakhodiv shchodo usunennya nedolikiv systemnoho kharakteru, shcho pryzvodyat' do nevykonannya rishen' natsional'nykh sudiv" [Resolution of the Cabinet of Ministers of Ukraine 222-p on Approval of the Plan of Priority Measures to Address Systemic Defects Resulting in Non-Enforcement of Rulings of National Courts], Feb. 11, 2010, archived at http://perma.cc/6R6C-T5LT. 
According to this resolution, the draft law on the budget for 2010 was supposed to designate funds for compliance with the European Court of Human Rights' pilot judgment, but the budget law that was ultimately adopted did not provide for these expenses. ${ }^{118}$ The Kharkiv Human Rights Protection Group reports that the Ministry of Labor and Social Policy noted this omission and stressed the "need to provide additional funds for the enforcement of court rulings" in the process of making amendments to the final law on the 2010 budget, but the amendments were not approved. ${ }^{119}$ Moreover, the Cabinet of Ministers' resolution noted the need for draft laws which would amend existing laws on limiting the forced sale of debtors' property, regulate enforcement of rulings of national courts against the state or state institutions, and protect creditors' rights. ${ }^{120}$ Although several draft laws were submitted in 2009 regarding these issues, they were recalled on March 11, 2010 by the new Cabinet of Ministers formed under Prime Minister Mykola Azarov according to article 105 of The Law on the Rules of Procedure of the Verkhovna Rada of Ukraine. ${ }^{121}$

\section{BudgetARY SHORTFALlS AND THE SyStem OF SOCIAL BENEFITS}

The second underlying cause of systemic non-enforcement in Ukraine is the country's expansive system of social benefits. The Ukrainian Constitution and legislation entitle numerous categories of people to benefits, a system inherited from Ukraine's Soviet past. By 2011, there were approximately 120 categories of beneficiaries, of which 45 were based on social needs, and 57 on work or professional grounds. ${ }^{122}$ At least 15 million Ukrainian citizens were entitled to benefits in 2011, and these benefits total between 3.8 and 5.8 billion US dollars per year. ${ }^{123}$ Of this, however, only a fraction is paid. Nazar Kulchytsky, the current commissioner of Ukraine to the European Court of Human Rights, explained that "in practice, it is not possible to pay all these benefits," so "people receive no payments, they go to court, [the] court delivers its judgments and obliges [the] state to pay all these amounts, but since they are not provided in the state budget it is not possible to execute" the

118. Id.

119. Property Rights, supra note 115, at 242.

120. Resolution of the Cabinet of Ministers of Ukraine 222-p on Approval of the Plan of Priority Measures to Address Systemic Defects Resulting in Non-Enforcement of Rulings of National Courts, supra note 117.

121. According to Article 105 of the Law on the Rules of Procedure of the Verkhovna Rada of Ukraine, a draft of a law introduced by the Cabinet of Ministers is considered to be void if it has not been passed in the first reading by the time this Cabinet quits office. See Law No. 1861-VI, on the Rules of Procedure of the Verkhovna Rada of Ukraine, February 10, 2010 (Ukr.), archived at http://perma.cc/NUS7-J27L.

122. Shcherbatyuk \& Yavorsky, supra note 110.

123. Shcherbatyuk \& Yavorsky, supra note 110. 
decisions. ${ }^{124}$ As a result, the state debt continues to grow year by year, while new rounds of judgments go unenforced. Yevhen Zakharov, the director of the Kharkiv Human Rights Protection Group, emphasized that the creation of many of the existing categories of beneficiaries was a form of "populism" designed to win support for politicians, and that to substantively reform the system of social payments, the government would have to target certain categories and eliminate others. ${ }^{125}$

In response to this issue, the Cabinet of Ministers of Ukraine instated regulations that authorize the government to adjust the annual amounts of social benefits, depending on the funds allocated for this purpose in the state budget. For example, the Law on the State Budget for 2012 states that the social benefits for veterans, children of war, Chernobyl liquidators, and many other categories of citizens eligible for social assistance will be determined by the Cabinet of Ministers of Ukraine "within available financial resources." $" 126$

A group of members of parliament opposed this principle, and challenged the Law on the State Budget for 2011 in the Constitutional Court. ${ }^{127}$ In the past, the Constitutional Court had repeatedly found that any government efforts to cut social benefits violated article 22 of the Ukrainian Constitution. ${ }^{128}$ In December 2011, the Constitutional Court reversed its

124. Interview by Carolyn Forstein with Nazar Kulchytsky, supra note 103.

125. Interview by Carolyn Forstein with Yevhen Zakharov, Director, Kharkiv Human Rights Protection Group, in Kharkiv, Ukr. (Mar. 3, 2012).

126. Zakon Ukrayiny "Pro Derzhavnyi byudzhet Ukrayiny na 2012 rik" [Law of Ukraine on the State Budget of Ukraine for 2012], VIDOMOSTI VERKHOVNOI RADY UKRAYINY [VVR] 2012,No. 34-35, Item 414, archived at http://perma.cc/JUU2-X35N.

127. Rishennya Konstytutsiynoho Sudu Ukrayiny u spravi za konstytutsiynymy podannyamy 49 narodnykh deputativ Ukrayiny, 53 narodnykh deputativ Ukrayiny, i 56 narodnykh deputativ Ukrayiny shchodo vidpovidnosti Konstytutsyi Ukrayiny punktu 4 rosdilu VII "Prykintsevi Polozhennya" Zakonu Ukrayiny "Pro Derzhavnyi byudzhet Ukrayiny na 2011 rik" [Decision of the Constitutional Court of Ukraine in the Case of the Constitutional Petitions of 49 People's Deputies of Ukraine, 53 People's Deputies of Ukraine, and 56 People's Deputies of Ukraine Concerning the Conformity with the Constitution of Ukraine of Item 4 of Chapter VII "Final Provisions" of Law of Ukraine on the State Budget of Ukraine for 2011], OfITSIYNYy ViSNYK UKRAYINY [OfFICIAL JOURNAL OF Ukraine] 2012 No. 3, Item 100, Dec. 26, 2011, [hereinafter Constitutional Court State Budget Case for 2011], archived at http://perma.cc/CU2F-W8A7, English summary archived at $\mathrm{http}: / /$ perma.cc/Y5QC-NDRD.

128. See, e.g., Rishennya Konstytutsiynoho Sudu Ukrayiny u spravi za konstytutsiynymy podannyamy 54 narodnykh deputativ Ukrayiny shchodo vidpovidnosti Konstytutsyi Ukrayiny (konstytutsiinosti) polozhen statei 44, 47, 78, 80 Zakonu Ukrayiny "Pro Derzhavnyy byudzhet Ukrayiny na 2004 rik" ta konstytutsiynym podannyam Verkhovnoho Sudu Ukrayiny shchodo vidpovidnosti Konstytutsyi Ukrayiny (konstytutsiinosti) polozhen chastyn dryhoi, tretyoi, chetvertoi statti 78 Zakonu Ukrayiny "Pro Derzhavnyy byudzhet Ukrayiny na 2004 rik" (Sprava pro zupynennya dii abo obmezhennya pil'g, kompensatsiy i garantiy) [Decision of the Constitutional Court of Ukraine in the Case of the Constitutional Petitions of 54 People's Deputies of Ukraine Concerning the Conformity with the 
stance. ${ }^{129}$ For the first time in its own history, the Constitutional Court ruled that social payments should be dependent on the socio-economic resources of the state, thereby granting the Cabinet of Ministers the ability to reduce social benefits based on the need to proportionally balance the social security of the population and the financial capacity of the state. ${ }^{130}$ In another decision on January 25, 2012, concerning the Pension Fund, the Constitutional Court again justified this distribution of power based on proportionality and the need to balance the budget. ${ }^{131}$

Constitution of Ukraine (Constitutionality) of the Provisions of Articles 78.2, 78.3 and 78.4 with the Law of Ukraine on Ukraine's State Budget for 2004 (the Case on Suspension or Restriction of Benefits, Compensations and Guarantees)], OFITSIYNYY VISNYK UKRAYINY [OfFicial Journal of Ukraine] 2004 No. 50, Item 3289, Dec. 30, 2004, archived at http://perma.cc/9ZLB-4B4K, English summary archived at http://perma.cc/LM8C-E932; Rishennya Konstytutsiynoho Sudu Ukrayiny u spravi za konstytutsiynym podannyam Verkhovnogo Sudu Ukrayiny ta 50 narodnykh deputativ Ukrayiny shchodo vidpovidnosti Konstytutsyi Ukrayiny (konstytutsiinosti) polozhen abzatsiv tretyoho, chetvertoho punktu 13 rozdilu XV "Prykintsevi Polozhennya" Zakonu Ukrayiny "Pro zagal'noobovyazkove derzhavne pensiyne strakhuvannya" ta ofitsiynoho tlumachennya polozhennya chastyny tretyoi statti 11 Zakonu Ukrayiny "Pro status suddiv" (Sprava pro riven pensii i shchomisyachnoho dovichnoho groshovoho utrymannya) [Decision of the Constitutional Court of Ukraine in the Case of the Constitutional Petitions of the Supreme Court of Ukraine and 50 People's Deputies of Ukraine on Conformity with the Constitution (Constitutionality) of Paragraphs 13.3 and 13.4 of Section XV "Final Provisions" of the Law of Ukraine "On General Mandatory State Pension Insurance" and the Official Interpretation of Provisions of Article 11.3 of the Law of Ukraine on Status of Judges (Case on the Pension Level and Lifetime Monthly Monetary Allowance)], OfitsiYnYy Visnyk UkRAYINY [OfFICIAL JoURNAL OF UkRAINE] 2005 No.42, Item 2662, Nov. 2, 2005, archived at http://perma.cc/NBQ6-N6TQ, English summary archived at http://perma.cc/WF9T-3YAR; Rishennya Konstytutsiynoho Sudu Ukrayiny u spravi za konstytutsiynym podannyam Verkhovnogo Sudu Ukrayiny shchodo vidpovidnosti Konstytutsyi Ukrayiny (konstytutsiinosti) okremykh polozhen statti 36, punktiv 20, 33, 49, 50 statti 71, statei 97, 98, 104, 105 Zakonu Ukrayiny "Pro Derzhavnyi byudzhet Ukrayiny na 2007 rik" (Sprava pro garantii nezalezhnosti suddiv) [Decision of the Constitutional Court of Ukraine in the Case of the Constitutional Petition of the Supreme Court of Ukraine as to the Conformity with the Constitution of Ukraine (Constitutionality) of Separate Provisions of Article 36, Items 20, 33, 49, 50 of Article 71, Articles 97, 98, 104, 105 of the Law of Ukraine on the State Budget of Ukraine for 2007 (Case on Guarantees of Independence of Judges)], OFITSIYNYY VISNYK Ukrayiny [OfFICIAL Journal of Ukraine] 2007 No. 54, Item 2184, Aug. 03, 2007, archived at http://perma.cc/4YMU-BTKW, English summary archived at http://perma.cc/4FKV-LGL7.

129. Constitutional Court State Budget Case for 2011, supra note 127.

130. Constitutional Court State Budget Case for 2011, supra note 127.

131. Rishennya Konstytutsiynoho Sudu Ukrayiny u spravi za konstytutsiynym podannyam pravlinnya Pensiynoho fondu Ukrayiny shchodo ofitsiynoho tlumachennya polozhen statti 1, chastyn pershoyi, druhoyi, tretyoi statti 95, chastyny druhoyi statti 96, punktiv 2, 3, 6 statti 116, chastyny druhoyi statti 124, chastyny pershoyi statti 129 Konstytutsiyi Ukrayiny, punktu 5 chastyny pershoyi statti 4 Byudzhetnoho Kodeksu Ukrayiny, punktu 2 chastyny pershoyi statti 9 Kodeksu Administrativnoho Sudochynstva Ukrayiny v systemnomu zv'yazku z okremnymy polozhennyamy Konstytutsiyi Ukrayiny [Decision of the Constitutional Court of Ukraine in the Case of the Constitutional Petition of 
The issue is both legally and politically controversial. Vsevolod Rechytsky, a constitutional expert with the Kharkiv Human Rights Protection Group, explains that while the Constitutional Court's decision appears reasonable and logical from an economic perspective, it creates "insoluble contradictions" in legal terms. ${ }^{132}$ Article 22 of the Ukrainian Constitution states that "the content and scope of the existing rights and freedoms shall not be diminished by an adoption of new laws or by introducing amendments to the effective laws," thereby prohibiting the government from eliminating or decreasing any types of social assistance. ${ }^{133}$ Rechytskyi argues that the socio-economic rights enshrined in the constitution are "designed not for the free market, capitalism and freedom, but for the planned economy, state ownership and distributive economic system," one which guarantees set levels of social benefits, regardless of economic development and performance. ${ }^{134}$ To effectively reform the system of social protection, the government would have to amend the Constitution, and go far beyond simply reducing benefit amounts based on the yearly budget.

In both of the above decisions, the Constitutional Court referred to European Court of Human Rights case law to justify its position, citing Airey v. Ireland and Kyartan Asmudson v. Iceland. ${ }^{135}$ However, the Constitutional Court overlooked important conclusions and implications of the European Court of Human Rights' rulings. While the European Court of Human Rights acknowledged the connection between the provision of socio-economic rights and the financial capabilities of the state, it also noted that the application of rules concerning this relationship should not create a disproportionate balance between individual human rights and the general interest. ${ }^{136}$ In addition, it is not just individual rights at stake, but the general public interest in the effectiveness the judicial system-the cornerstone of any legal system, regardless of the level of financial security

the Board of the Pension Fund of Ukraine Concerning Official Interpretation of the Provisions of Articles 1, 95.1, 95.2, 95.3, 96.2, 116.2, 116.3, 116.6, 124.2, 129.1 of the Constitution, 4.1.5 of the Budget Code of Ukraine, 9.1.2 of the Code of Administrative Proceedings of Ukraine in Systematic Connection with Some Provisions of the Constitution], OfitsiYnYy Visnyk Ukrayiny [OfFicial Journal of Ukraine], 2012 No. 11, Item 422, Jan. 25, 2012 [hereinafter Constitutional Court Pension Fund Case], archived at http://perma.cc/M6EQ-5ULM, English summary archived at http://perma.cc/WA4C-DD8G.

132. Constitutional Process in Ukraine: 2011-Early 2012, Current Trends and Summary, in Human Rights in Ukraine 2010-2011, Human Rights Organizations Report 19, 28 (Yevhen Zakharov, ed., 2012) [hereinafter Constitutional Process in Ukraine].

133. KonstytutsiYa UkRAyiny [CONSTitution OF Ukraine] June 28, 1996, art. 22, archived at http://perma.cc/3VTA-WHVS.

134. Constitutional Process in Ukraine, supra note 132, at 28.

135. Constitutional Court State Budget Case for 2011, supra note 127, at 4; Constitutional Court Pension Fund Case, supra note 131, at 4.

136. Kyartan Asmudson v. Iceland, 2004 Eur. Ct. H. R. § 45; Airey v. Ireland, 32 Eur. Ct. H.R. (ser. A) § 26 (1979). 
of the state.

The proposed cut in benefits was strongly criticized by civil society and sparked protests across Ukraine. In September 2011, in response to the government's proposal to reduce benefits, thousands of veterans of the Soviet war in Afghanistan and the cleanup of the Chernobyl nuclear disaster picketed in front of the Verkhovna Rada in Kyiv. ${ }^{137}$ Public outrage continued throughout the fall. On November 15, 2011, dozens of Chernobyl veterans went on hunger strike in Donetsk, while hundreds more gathered in protest. ${ }^{138}$ In Kyiv, thousands of protestors repeatedly gathered to protest the proposed cuts, at one point storming the gates of the Verkhovna Rada, and another thirty veterans went on hunger strike. ${ }^{139}$ The protests in Kyiv and smaller actions in Kharkiv were spurred onwards by clashes between the Donetsk protestors and local police, where the hunger strike only ended when the local administration promised to pay the veterans' benefits in full for the months of November and December. ${ }^{140}$ Following the abovementioned Constitutional Court decisions, some 100 Chernobyl liquidators held a multi-day protest on Kharkiv's Freedom Square in January 2012. ${ }^{141}$

\section{POLITICAL WILL}

The Ukrainian government's persistent failure to craft and pass legislation seeking to ensure the enforcement of court decisions reflects the structural nature of the problem, but also stems from an obvious lack of

137. Ukrainian Veterans Protest Planned Cuts in Benefits, RADIo FreE Europe/RADio LIBERTY (Sept. 20, 2011), http://www.rferl.org/content/ukrainian_veterans_protest_planned_ cut_in_benefits/24334723.html, archived at http://perma.cc/VDK5-T7Y9.

138. Ukrainian Pensioners Attack Donetsk Governor's Office, RADIO FreE EUROPE/RADIO LIBERTY (Nov. 28, 2011), http://www.rferl.org/content/ukrainian_pensioners _attack_donetsk_governors_office/24404893.html, archived at http://perma.cc/ZS92-6PCM.

139. Chornobyl Cleanup Workers Protest Cancellation of Social Benefits, KYIV PosT (Nov. 1, 2011), http://www.kyivpost.com/news/politics/detail/116051/, archived at http://perma.cc/KX92-8JNQ; Ukrainians Rally In Kyiv To Support Donetsk Protesters, RADIO FREE EUROPE/RADIO LIBERTY (Nov. 30, 2011), http://www.rferl.org/content/ ukrainians_rally_in_kyiv_to_support_donetsk_protesters/24406928.html, archived at http://perma.cc/9632-354G; Ukrainian Protestors Start 'Dry' Hunger Strike, RADIO FreE EUROPE/RADIO LIBERTY (Dec. 8, 2011), http://www.rferl.org/content/ukrainian_protesters_ start_dry_hunger_strike/24416056.html, archived at http://perma.cc/9WCB-S5U9.

140. Ukrainian Hunger Strikers End Protest After Pledge of Payments, RADIO FreE EUROPE/RADIO LIBERTY (Dec. 12, 2011), http://www.rferl.org/content/ukrainian chornobyl_cleanup_hunger_strikers_end_payments_pledge/24419853.html, archived at http://perma.cc/R5LE-VPFU.

141. Yulia Zhuravl'ova, U Kharkovi Chornobyl'tsi Vystupayut' Proti Rishennya Konstytutsiynoho Sudu shchodo Sotsial'nyx Vyplat [In Kharkov Chornobyl Veterans Oppose the Decision of the Constitutional Court on Social Benefits], Radio Svoboda (Jan. 27, 2012), http://www.radiosvoboda.org/content/article/24465639.html, archived at http://perma.cc/J55V-EP9C. 
political will on the side of the Ukrainian government. The challenge of reforming ingrained institutions, namely state-owned enterprises and the system of social benefits, is a legacy of communism shared by many postSoviet countries. ${ }^{142}$ In Ukraine, the interests of the political elite and the composition of the country's economy have stymied any serious effort to address these issues.

This gridlock is particularly evident in relation to the current moratoriums on the forced sale of assets of state-owned or energy-related companies. Nazar Kulchytsky explains that "most entities which are protected by different moratoriums have a powerful lobby among all parliamentary factions, and it is not a secret that many of them are either owned directly by members of the Ukrainian parliament or are in their sphere of interests." 143 These deputies have no interest in removing the moratoriums or establishing a mechanism which would effectively hold companies responsible for their debts, and thus might have an impact on deputies' personal financial interests. Under the current system, companies "can make debts, and then the state will pay for the debts," causing a large strain on the state budget but none on the individual finances of politicians. ${ }^{144}$

There are also significant political incentives to delay any reform of the benefits system. Cutting social benefits is enormously unpopular among the Ukrainian population, and elections are still meaningful in Ukraine. This undoubtedly impacted the failure to pass any reform prior to both the 2010 presidential and the 2012 parliamentary elections. Although many benefits often go unpaid, citizens are aware of their legal rights, including their right to apply to the European Court of Human Rights, and feel morally entitled to formally qualify for such benefits, even if they often fail to receive them in practice. ${ }^{145}$ The Ukrainian Helsinski Human Rights Union argues that

[g]iven the lack of funding for these benefits even at the present time when the law clearly establishes their size and everyone has the opportunity to defend their rights in court, it is entirely clear that the way out of the situation proposed by the Cabinet of Ministers is a means of avoiding liability

142. See, e.g., Hilary Appel, Eur. Union Ctr. of Cal., International Imperatives AND TAX REFORM: LESSONS FROM POSTCOMMUNIST EUROPE (2003), archived at http://perma.cc/38TK-QBEC; Kim Lane Scheppele, A Realpolitik Defense of Social Rights, 82 TEX. L. REv. 1921 (2004); Andrey Meleshevich et al., Juristocracy and the Protection of the Second-Generation Positive Rights by the Constitutional Court of Ukraine, 103 NAT'L U. of Kyiv-Mohyla ACAD. ReV., Legal Stud. 1, 13-20 (2008).

143. Interview by Carolyn Forstein with Nazar Kulchytsky, supra note 103.

144. Id.

145. See supra Part VI (discussing protests in response to proposed budget cuts). 
for not implementing the socio-economic rights and their guarantees stipulated by law. ${ }^{146}$

This policy would allow the government not only to cut the amount of social benefits available to the population but also to reduce the number of categories of social benefits, and thus the number of potential European Court of Human Rights cases, without addressing the fundamental systemic failure to enforce court decisions. Moreover, individual deputies could thus blame decreases in benefit payments on the budget rather than their own initiatives.

Another factor is the sheer expense of the guaranteed benefits. It is simply less expensive for the government to fail to fulfill legal obligations and only settle debts with those individuals who take their cases to court, than to pay all of its existing debts. Volodomyr Yavorsky, the former chairman of the Ukrainian Helsinski Human Rights Union, explained that many individuals do not pursue their cases through all possible legal measures, with only a small fraction actually taking their cases to the European Court of Human Rights, at which point the government is often willing to pay. ${ }^{147}$ While "expenses for the government are getting bigger and bigger from year to year, for example for parliament, for the president and for the Cabinet of Ministers," these actors now "want to cut all expenses on social payments." 148 Yavorsky argues that if the government is seeking to balance the budget, they should "cut all payments, not only to the people." ${ }^{149}$ In order to maintain the current wide scope of social benefits and both fully fund them and ensure the enforcement of court decisions, the government would have to cut funds elsewhere, which would likely hurt politicians' individual financial interests.

Looking at Ukraine's history of legislative reform, the larger political context also plays an important role. When Yanukovych and the Azarov government came to power, existing draft laws and past proposals were scrapped, even though the Yushchenko government had been discussing the issue of non-enforcement for years. ${ }^{150}$ Additionally, certain actors within the government appear more committed to reform than others. Ivanna Ilchenko at the Ministry of Justice estimated that around 70 percent of the proposals drafted by the Ministry of Justice are not considered by

146. Maxim Shcherbatyuk \& Volodymyr Yavorsky, New Draft Bill on Enforcement of Court Rulings, Same Old Problems, Ukrainian Helsinki Human Rights Union (Sept. 26, 2011, archived at http://perma.cc/RD2Q-BBHQ).

147. Interview by Carolyn Forstein with Volodymyr Yavorsky, Director, Ukrainian Helsinki Human Rights Union, in Kyiv, Ukr., (Jan. 20, 2012).

148. Id.

149. Id.

150. See e.g., Law No. 1861-VI, supra note 121. 
parliament. ${ }^{151}$ The Ukrainian Helsinski Human Rights Union noted that the Ministry of Labor unsuccessfully pushed for enforcement of court decisions to be its own line in the state budget. ${ }^{152}$ Even if specific actors in the government work for reform, they can succeed only if political will exists in parliament. Given the current dominance of the Party of Regions in every branch of government, this will must stem at least in part from President Yanukovych and his political organization. ${ }^{153}$

Lastly, the timidity of the European and international communities has impacted Ukraine's response. Since the fall of 2011, international attention has focused on the trial and sentence of Yulia Tymoshenko, with multiple European leaders condemning the verdict as politically motivated and urging the Ukrainian government to secure her release. ${ }^{154}$ Comparatively little criticism has focused on the persistent problem of nonenforcement of judicial decisions and Ukraine's contempt for the pilot judgment, despite the fact that this issue is at the heart of rule of law development, and that Ukraine has ignored Europe's premier human rights body. While international pressure is not always successful-as demonstrated by Tymoshenko's continued imprisonment - the lack of international attention or any repercussions from the Council of Europe has made it easier for the Ukrainian government to drag its feet on reform.

\section{DRAFT LAW № 9127 AND LAW № 4901-VI}

The Ukrainian government introduced draft law № 9127 On Guarantees of the State Concerning the Execution of Court Decisions in the Verkhovna Rada in September of 2011 as a response to the Ivanov pilot judgment. ${ }^{155}$ The Rada adopted Law of Ukraine № 4901-VI of the same name in May of 2012. ${ }^{156}$ These two documents had significant fundamental

151. Interview by Carolyn Forstein with Ivanna Ilchenko, Lawyer, Ministry of Justice of Ukraine, in Kyiv, Ukr. (Feb. 2, 2012).

152. Property Rights, supra note 115, at 242.

153. See, e.g., Mykhailo Minakov, Foundation for Good Politics, Ukraine's Political Development in 2012-2013, (May 17, 2013, archived at http://perma.cc/LHZ5-TBW6).

154. See, e.g., Maria Danilova, Ukraine's Tymoshenko Sentenced to 7 Years in Jail, THE WASHINGTON Times (Oct. 11, 2011, archived at http://perma.cc/7MAA-AAXQ); Steven Pifer, Ukraine, Europe and Tymoshenko: Does Yanukovych Get It?, BroOKInGS (Sept. 19, 2011, archived at http://perma.cc/4JEE-28KS).

155. See Draft Law No. 9127, supra note 69; Proyekt Zakony pro harantyi derzhavy shchodo vykonannya sudovyx rishen [Draft Law on Guarantees of the State Concerning the Enforcement of Court Decisions], KARTKA ZAKONOPROYEKTU [RECORD OF THE DRAFT LAW] (Sept. 8, 2011), available at http://w1.c1.rada.gov.ua/pls/zweb2/webproc4_1?pf3511=41092.

156. See Law No. 4901-VI, supra note 81; Zakon Ukrayiny "Pro Harantyi Derzhavy shchodo Vykonannya Sudovyx Rishen" [Law of Ukraine "On Guarantees of the State Concerning the Enforcement of Court Decisions"], OfITSIYNYY VISNYK UKRAYINY [OfFicial Journal of Ukraine], 2012 No. 49, Item 1919, July 6, 2012, [hereinafter Law No. 4901], archived at http://perma.cc/MC96-9TW4. 
differences. While draft law № 9127 was reviewed by the Committee of Ministers of the Council of Europe, and included several important provisions called for by the European institutions, the majority of these provisions were not included in Law № 4901-VI. ${ }^{157}$ Although at the time of this study it is impossible to offer final or even interim conclusions about the impact of this law on the enforcement of court decisions, a preliminary study of the law shows that it does not address several obstacles to effective enforcement, and possibly creates a legal conflict and additional problems.

Draft law No. 9127 consisted of two sections: "Peculiarites [sic] of Execution of Court Decisions" and "Concluding Provisions."158 As noted above, the bill contained several important provisions, which the Council of Europe had long urged Ukraine to introduce. ${ }^{159}$ First, article 3 of the the first section, "Peculiarites [sic] of Execution of Court Decisions," expressly identified the government agency responsible for enforcing court decisions concerning debts owed by public bodies, a gap which had been the source of substantial confusion and inefficiency. ${ }^{160}$ According to the draft law, these responsibilities should "be carried out by the State Treasury Service of Ukraine within appropriate budget allocations by debiting funds from a State authority['s] accounts, and in the absence of designated allocations of this State authority - with funds provided by [the] budget program for the execution of court decisions."161

Second, article 5 of this same section established the government's responsibility for prolonged non-enforcement of court decisions, and procedures for the payment of compensation for delays. According to the draft law, in the event that the State Treasury Service of Ukraine failed to transfer payment awarded by a court decision within three months, the prevailing party would receive compensation for the delay "in the amount of $3 \%$ per annum [of the] unpaid amount . . a the expense of the budget program for the execution of court decisions." 162

Third, the bill's second section, "Concluding Provisions," acknowledged that the law "On Introducing a Moratorium on the Forced

157. $I d$.

158. The English translations of the section titles and articles of the draft law are from a translation of the law provided by the Government Agent of Ukraine to the European Court of Human Rights to the Council of Europe. Letter from the Government Agent of Ukraine to the European Court of Human Rights (July 30, 2012), archived at http://perma.cc/F9XRU5NA. Based on the original Ukrainian, the sections could also be translated as "Aspects of Enforcement of Court Decisions," and "Concluding and Transitional Provisions." For the sake of clarity, we use the translation provided by the Government Agent.

159. Comm. of Ministers, Decision Cases No. 24 - Yuri Nikolaevich and Zhovner group against Ukraine, CM/Del/Dec (2012) 1136/24 (2012). See also Draft Law No. 9127, supra note 69.

160. Draft Law No. 9127, supra note 69.

161. Draft Law No. 9127, supra note 69.

162. Draft Law No. 9127, supra note 69. 
Sale of State Property," had expired. ${ }^{163}$ Fourth, the bill eliminated the special rules for the enforcement of court decisions concerning recovery of debts from companies included on the fuel and energy complex registry. ${ }^{164}$ As Maxim Shcherbatyuk and Volodymyr Yavorsky of the Ukrainian Helsinski Human Rights Union emphasized, removing these moratoriums is an essential aspect of resolving systemic non-enforcement. ${ }^{165}$ Fifth, the second section obligated the Cabinet of Ministers, within three months from the day the law went into effect, to submit bills to the Verkhovna Rada to bring other legislative acts in line with the provisions of this law. ${ }^{166}$

The most controversial innovation of the second section of the draft law was the provision granting the Cabinet of Ministers the right to adjust social spending based on the annual budget. ${ }^{167}$ As described above, the bill's proposed reduction of benefits provoked sharp criticism from civil society and nationwide protests.

Despite the draft law's shortcomings, the Committee of Ministers of the Council of Europe called on the Ukrainian parliament in September of 2011 to adopt the document in full and without delay. ${ }^{168}$ However, the Verkhovna Rada's response was both delayed and limited. The draft law was passed in its second and final reading nine months later in June of 2012, in a much reduced form. ${ }^{169}$ Only the first section of the draft law was included, while the second section with the revised title "Concluding Provisions" was truncated to two sentences: "[T]his Law enters into force on 1 January 2013. The Cabinet of Ministers of Ukraine has until 1 January 2014 to prepare and submit to the Verkhovna Rada of Ukraine proposals for amendments to laws of Ukraine, arising as a result of this Law."170

In contrast to the draft law, Law No. 4901-VI did not discuss lifting the moratoriums on the forced sale of property of public companies or entities included on the fuel and energy complex registry. ${ }^{171}$ Instead of a period of three months, the Law grants the Cabinet of Ministers a full year, through January 1, 2014, to submit draft legislation to parliament to bring

163. Draft Law No. 9127, supra note 69.

164. Draft Law No. 9127, supra note 69.

165. Shcherbatyuk \& Yavorsky New Draft, supra note 146.

166. Draft Law No. 9127, supra note 69.

167. Draft Law No. 9127, supra note 69.

168. Comm. of Ministers, Interim Resolution Execution of the Pilot Judgment of the European Court of Human Rights Yuriy Nikolaevich Ivanov Against Ukraine and of 386 Cases Against Ukraine Concerning the Failure or Serious Delay in Abiding by the Final Domestic Courts' Decisions Delivered Against the State and its Entities as well as the Absence of an Effective Remedy, CM/ResDH (2011) 184 (2011), archived at http://perma.cc/34Z-5525.

169. See Law No. 4901-VI, About Guarantees of the State Concerning Execution of Judgments, June 5, 2012 (Ukr.).

170. Id.

171. See Law No. 4901-VI, supra note 81 . 
other existing laws into conformity with the provisions of Law No. 4901VI. ${ }^{172}$ Nothing is mentioned about bringing legal acts of the Cabinet of Ministers into compliance with Law No. 4901-VI. ${ }^{173}$ This preliminary analysis of the Law of Ukraine On Guarantees of the State Concerning the Enforcement of Court Decisions suggests that the law not only fails to remove some of the key obstacles to effective enforcement of Ukrainian court decisions, but also fails to establish a timeline or basis for addressing them in the future.

The circumstances under which the law was passed further explain the differences between the bill and the subsequent law. As argued in the next section, the haste and context in which Law No. 4901-VI was passed indicate that a primary reason for its passage, in this form, was to demonstrate the Ukrainian government's responsiveness to the Council of Europe, rather than to establish an effective mechanism for the enforcement of court decisions.

According to the transcript of a parliamentary session held on June 5, 2012, First Deputy Chairman Adam Martynyuk acknowledged this factor in an address to members of parliament concerning the law in consideration:

Dear colleagues, we now have to consider a very interesting 'archaic' draft law (9127), on guarantees of the state concerning the enforcement of court decisions. This is its second reading ... I will explain, why it is today, because tomorrow or the day after there will be the Council of Europe's relevant meeting, where they will consider how Ukraine has responded to these questions. And on Thursday it will already be too late to consider [the law]. It must be considered today, based on the schedule of work of the European bodies. ${ }^{174}$

Martynyuk also explained that the vote would only concern the first part of draft law No. 9127, the section on "Peculiarites [sic] of Execution of Court Decisions," as "we have agreed that we will not consider the concluding and transitional [provisions] at all, because these concern changes to laws that we do not need to speak about."

Despite this substantive cut, the draft law was not fully prepared in time for its second reading, and the final content of the law was not

172. See Law No. 4901-VI, supra note 81.

173. See Law No. 4901-VI, supra note 81.

174. Zasidannya Sorok Tretye [43rd Meeting, Evening], Tenth Session of the Verkhovna Rada of Ukraine, Sixth Convocation, February-July, 2012. Verbatim Report of Plenary Meetings, June 5, 2012, available at http://static.rada.gov.ua/zakon/skl6/10session/ STENOGR/05061210_43.htm (alteration added).

175. Id. (alteration added). 
presented to members of parliament. Chairman Martynyuk, with the support of Rapporteur MP Dmytro Prytyka, the former head of the Supreme Economic Court, criticized this shortcoming in the parliamentary session of June 5, 2012, stressing that the committee had been "too lazy to prepare" a final, updated draft of the law, and as a result it was "difficult to formulate" what exactly he was being asked to vote on. ${ }^{176}$

As the draft law was not prepared for a second reading at the time of voting, which took place at 4:32 p.m., it received only 57 votes out of a possible 450, and was rejected. ${ }^{177}$ A mere hour and a half after this vote, at the suggestion of MP Mykhaylo Chechetov, the Verkhovna Rada decided to resume consideration of draft law No. 9127. ${ }^{178}$ At 6:07 p.m., 259 members of parliament voted to pass this draft law in its second and final reading. ${ }^{179}$

As might have been expected, the Council of Europe's reaction to the passage of Law No. 4901-VI On Guarantees of the State Concerning the Enforcement of Court Decisions was restrained. The Committee of Ministers welcomed the passage of this law, and at the same time requested that Ukraine send a copy of the text of the law, together with information on its entry into force and its compliance with the requirements of the European Court of Human Rights's pilot judgment in the Ivanov case. ${ }^{180}$ On September 19, 2012, the Department for the Execution of Judgments of the European Court of Human Rights issued a Memorandum assessing the current situation pursuant to the Ivanov judgment and the Zhovner group of cases concerning the structural problem of non-enforcement or delayed enforcement of domestic judicial decisions. ${ }^{181}$ Discussing Law No. 4901-VI On Guarantees of the State Concerning the Enforcement of Court Decisions, the Memorandum noted that many concerns raised by the court in its earlier documents regarding the problem of execution of judicial decisions in Ukraine "do not appear to have been addressed in the final version of the law as adopted."

On September 20, 2012, the Committee of Ministers endorsed the

176. $I d$.

177. Id.

178. Id.

179. Id.

180. Comm. of Ministers, Communication on the Activities of the Committee of Ministers, Report by the Chair of the Committee of Ministers to the Parliamentary Assembly (May - June 2012), CM/AS (2012) 5 ๆ 12 (2012), archived at http://perma.cc/Y4SW-BB3F.

181. Comm. of Ministers, Case of Yuriy Nikolayevich Ivanov Against Ukraine, and Group of Cases of Zhovner Against Ukraine. Pilot Judgment and Group of Cases Concerning the Non-Enforcement or Delayed Enforcement of Domestic Judicial Decisions, Assessment of the Measures Already Taken and of the Measures Still Envisaged, and Memorandum Prepared by the Department for the Execution of Judgments of the European Court of Human Rights, CM/Inf/DH (2012) 29 ๆ 1 (2012), https://wcd.coe.int/ViewDoc.jsp? id $=1978383 \&$ Site $=$ CM.

182. Id. ๆ 19. 
evaluation presented in this Memorandum, "urged the Ukrainian authorities once again to take the necessary measures as a matter of utmost urgency in order to resolve the problem of non-enforcement" and "invited the Ukrainian authorities to provide further and detailed information in the light of the above-mentioned memorandum in due time for the 1,157 th meeting (December 2012)." ${ }^{, 183}$ In its reply, the Government of Ukraine attempted to address the Memorandum's concerns and informed the Committee of Ministers that, in order to resolve the outstanding problems, the Government had "drafted the Law on amendment of the Law On Guarantees of the State Concerning the Execution of Court Decisions" which would be submitted to the Ukrainian Cabinet of Ministers "in the nearest future." 184

The following Interim Resolution adopted by the Committee of Ministers on December 6, 2012, uses the toughest language to date against Ukraine. The Committee of Ministers recognizes that since 2004 it "has repeatedly called upon the Ukrainian authorities to adopt, as a matter of priority, the necessary measures in its domestic legal system" and reaffirms "most firmly that the High Contracting Parties to the Convention have undertaken to abide by the final judgment of the Court in any case to which they are parties and that this obligation is unconditional." 185 The Resolution again "urges the Ukrainian authorities to adopt as a matter of utmost priority the necessary measures in order to resolve the problem of nonenforcement of domestic judicial decisions and to fully comply with the pilot judgment with no further delay." 186 The Committee of Ministers "profoundly deplor[es]" that the pilot judgment "still remains to be fully executed and that this situation poses a serious threat to the respect of the rule of law and to the effectiveness of the Convention system."187

\section{A COMPARISON CASE: RUSSIA}

Just nine months prior to its judgment in Ivanov $v$. Ukraine, the European Court of Human Rights issued a pilot judgment against Russia

183. Comm. of Ministers, Decision Cases No. 26 - Yuriy Nikolayevich Ivanov and Zhovner Group Against Ukraine, CM/Del/Dec (2012) 1150/26 qף 6-7 (2012), http://perma.cc/X82X-7R3K.

184. Comm. of Ministers, Communication from Ukraine Concerning the Case of Yuriy Nikolayevich Ivanov Against Ukraine (Application No. 40450/04), DH-DD (2012) 1065 ๆ 6 (2012).

185. Comm. of Ministers, Interim Resolution Execution of the Judgments of the European Court of Human Rights Yuriy Nikolayevich Ivanov Against Ukraine and the Zhovner Group of 389 Cases Against Ukraine Concerning the Non-Enforcement or Delayed Enforcement of Domestic Judicial Decisions and the Lack of an Effective Remedy in Respect Thereof, CM/ResDH (2012) 234 (2012), archived at http://perma.cc/V6HE-YMRA.

186. Id.

187. Id. (alteration added). 
that similarly concerned the systemic non-enforcement of domestic judgments. In Burdov v. Russia (No. 2), the court found violations of articles 6, 13, and article 1 of protocol 1 of the European Convention, and granted Russia six months to set up a new domestic remedy and twelve months to resolve all pending cases. ${ }^{188}$ While Russia exceeded the sixmonth deadline, the government passed two new federal laws establishing a domestic mechanism and settled all pending cases within a year from the day the judgment became final. ${ }^{189}$ The following section looks at the Burdov (No. 2) case and Russia's response, and contrasts the impact of the pilot judgment procedure on Russia with its impact on Ukraine.

Anatoliy Burdov, the applicant in Burdov v. Russia (No. 2), is a Russian national who was called up by the Soviet authorities to assist in the emergency cleanup of the Chernobyl nuclear disaster. ${ }^{190}$ Burdov was not new to the European Court of Human Rights; his first case, Burdov v. Russia, was the very first court judgment issued against Russia. ${ }^{191}$ Burdov worked at the Chernobyl site for three months between October 1986 and January 1987, where he "suffered from extensive exposure to radioactive emissions." $" 192$ As a result, he was entitled to social payments in compensation for the damage to his health. Burdov repeatedly failed to receive these payments on time and in full, and sued the relevant state authorities multiple times beginning in 1997. ${ }^{193}$ The Russian domestic courts repeatedly found in his favor, but several of their judgments went unenforced for significant periods of time.

The first Burdov v. Russia case was decided on May 7, 2002. ${ }^{194}$ The court found violations of article 6 and of article 1 of protocol No. 1, "on account of the authorities' failure for years to take the necessary measures to comply" with the domestic court decisions issued in Burdov's favor. ${ }^{195}$ However, although the Russian authorities compensated him for the delays in enforcement mentioned in the European Court of Human Rights case and initiated several administrative reforms to address the issues underlying the violations, Burdov continued to face delays in receiving his social benefits. ${ }^{196} \mathrm{He}$ again pursued legal action, resulting in five new domestic decisions in the Shakhty Town Court in his favor beginning in 2003. ${ }^{197}$

188. Burdov v. Russia (No. 2), 2009 Eur. Ct. H.R., archived at http://perma.cc/LK8AZHLR.

189. Eur. Ct. Hum. Rts., Press Unit, Pilot Judgments: Factsheet 3 (2013), archived at http://perma.cc/3W5E-GHLV.

190. Burdov (No. 2) 7.

191. Burdov (No. 2) 99.

192. Burdov (No. 2) 7.

193. Burdov (No. 2) 99.

194. Burdov (No. 2) 99.

195. Burdov (No. 2) 9.

196. Burdov (No. 2) \11-21.

197. Burdov (No. 2) ๆף 11-21. 
These decisions concerned ongoing delays in payments, payment of interest for past delays between 1999 and 2001, raises in his monthly allowances for food and health compensation, and compensation for more recent delays in payments. ${ }^{198}$ In the first three cases, it took over a year for the judgment to be executed in full, while the last two, both issued in 2007, were enforced within seven months. ${ }^{199}$

The European Court of Human Rights found that the length of the delays in enforcing the first three judgments constituted violations of article 6 and article 1 of protocol 1, while the last two judgments were enforced in reasonable periods of time. ${ }^{200}$ As in the Ivanov judgment, the court emphasized that neither "[t]he complexity of the domestic enforcement procedure or of the State budgetary system," nor the "lack of funds or other resources" could be cited as justifications for the failure to enforce a judgment. ${ }^{201}$ Burdov did not complain under article 13, but the European Court of Human Rights, noting that many of the past and pending cases concerning non or delayed enforcement complained about the lack of an effective domestic remedy, decided to consider and found a violation of article $13 .^{202}$ The court concluded that "there was no effective domestic remedy, either preventive or compensatory, that allows for adequate and sufficient redress in the event of violations of the Convention on account of prolonged non-enforcement of judicial decisions delivered against the State or its entities." 203

The persistence of this issue led the court to apply the pilot judgment procedure, noting that over 200 previous judgments against Russia concerned the same issues and that prolonged non-enforcement continued to impact a large number of people in Russia. ${ }^{204}$ In the Burdov (No. 2) judgment, the European Court of Human Rights set a deadline of six months for Russia to "introduce a remedy which secures genuinely effective redress" for individuals whose domestic court decisions go unenforced, and twelve months to resolve over 700 cases "concerning similar facts" which were currently pending at the European Court of Human Rights. ${ }^{205}$ The court also decided to adjourn any new cases concerning non-enforcement for one year. ${ }^{206}$

\footnotetext{
198. Burdov (No. 2) ๆๆ 11-21.

199. Burdov (No. 2) ๆף 11-21.

200. Burdov (No. 2) $1986,88$.

201. Burdov (No. 2) 70.

202. Burdov (No. 2) 9 ๆ 89, 117.

203. Burdov (No. 2) 9117 . Burdov also complained about discrimination under article 14 , but this complaint was rejected by the court.

204. Burdov (No. 2) $\uparrow 122$.

205. Burdov (No. 2) ๆ甲 133, 141-146.

206. Burdov (No. 2) 9 ๆ 143.
} 


\section{RUSSIA'S HISTORY OF NON-ENFORCEMENT}

Like Ukraine, prior to being issued a pilot judgment, Russia had long acknowledged and discussed the systemic problems of delayed and nonenforcement of domestic judgments, internally and with the Council of Europe. ${ }^{207}$ However, both the nature of the problem in Russia and Russia's past actions and attempts at reform differed from the situation in Ukraine. Following the original Burdov case in May 2002, Russia, in addition to fulfilling the individual measures towards Burdov, enforced over 5000 similar domestic judgments concerning allowances for Chernobyl victims and "improved its budgetary process to ensure that the necessary budgetary means are allocated to social security bodies." ${ }^{208}$ In April 2004, a Russian law entered into force establishing a new system of indexation, under which the allowances owed to Chernobyl victims are calculated based on the inflation rate, rather than on the less predictable cost of living index used previously. ${ }^{209}$ In December 2004, the Committee of Ministers adopted a resolution observing that "the more general problem of non-execution of domestic court decisions in the Russian Federation [was] being addressed by the authorities, under the Committee's supervision, in the context of other pending cases" and resolved to conclude monitoring the implementation of the Burdov judgment. ${ }^{210}$

Over the next few years, the Russian government implemented several significant reforms addressing systemic non-enforcement. In 2005, a new federal law added a chapter to the Budgetary Code to include a special execution procedure for judgments against the state and statefinanced entities, which made the Federal Treasury responsible for judgments against entities funded by the state budget, and the Ministry of Finance for those against the state itself. ${ }^{211}$ The following year, in October

207. Comm. of Ministers, Non-Enforcement of Domestic Judicial Decisions in Russia: General Measures to Comply with the European Court's Judgments, CM/Inf/DH (2006) 19 rev3 9 甲 1-5 (2007), archived at $\mathrm{http}: / /$ perma.cc/KFJ8-Q2RF.

208. Comm. of Ministers, Appendix to Resolution Concerning the Judgment of the European Court of Human Rights of 7 May 2002 (Final on 4 September 2002) in the Case of Burdov Against the Russian Federation, ResDH (2004) 85 (2004), archived at http://perma.cc/99R4-LPFN.

209. Id.

210. Id.

211. Non-Enforcement of Domestic Judicial Decisions in Russia: General Measures to Comply with the European Court's Judgments, supra note 207, ๆ 4; Federal'nyi Zakon RF o vnesenii izmeneniy v Byudzhetnyy Kodeks Rossiiskoi Federatsii, Grazhdanskiy Protsessual'nyy Kodeks Rossiiskoi Federatsii, Arbitrazhnyy Protsessual'nyy Kodeks Rossiiskoi Federatsii i Federalnyy Zakon 'Ob ispolnitel'nom proizvodstvye' [Federal Law of the Russian Federation on Amending the Budgetary Code of the Russian Federation, the Code of Civil Procedure of the Russian Federation, the Arbitration Code of the Russian Federation, and the Federal Law 'On Enforcement Proceedings'], RossiIsKaia Gazeta [Ros. Gaz.] Dec. 30, 2005, No. 3965. 
2006, high-level officials from the Russian judicial, legal, and law enforcement systems attended a roundtable held at the Council of Europe in Strasbourg to discuss non-enforcement. ${ }^{212}$ Two important legislative reforms were then adopted in 2007. In October, a new Federal Law On Enforcement Proceedings came into effect. ${ }^{213}$ The Ministry of Finance and the Treasury also revised administrative procedures to improve the enforcement process. ${ }^{214}$ The Committee of Ministers praised Russia for these reforms, noting that they reflected the Committee's own recommendations, while cautioning that they had not appeared to fully remedy non-enforcement. ${ }^{215}$

A 2007 memorandum of the Committee of Ministers on Russia, similar to the 2007 memorandum on Ukraine, examines the root causes of non-enforcement and efforts taken to address them. The Russian memorandum notes that the Russian authorities recognized the Committee's concerns, and acknowledged that the main obstacle was not insufficient funding but "complicated budgetary relations between the federal authorities and the authorities of the subjects of the Russian Federation." ${ }^{216}$ Primary responsibility for enforcement of judgments changed multiple times between 1997 and 2005, shifting first from the bailiffs service to the regional bodies of the Ministry of Finance, and finally to the federal level Ministry of Finance. Administrative problems, such as "inefficiencies within the bailiff system, a lack of coordination between domestic agencies and the domestic court's failure to clearly identify the debtor," all hindered the practical enforcement of judgments. ${ }^{217}$ Moreover, issues with disbursement of payments, namely that "relevant authorities lack[ed] funds and there [was] confusion regarding administrative

212. Non-Enforcement of Domestic Judicial Decisions in Russia: General Measures to Comply with the European Court's Judgments, supra note 207, 95.

213. Federal'nyi Zakon RF ob ispolnitel'nom proizvodestvye [Federal Law of the Russian Federation on Enforcement Proceedings], RossisskaiA GAZETA [Ros. GAz.] Oct. 6, 2007, No. 4486; Comm. of Ministers, Interim Resolution Execution of the Judgments of the European Court of Human Rights in 145 Cases Against the Russian Federation Relative to the Failure or Serious Delay in Abiding by Final Domestic Judicial Decisions Delivered against the State and its Entities as well as the Absence of an Effective Remedy, CM/ResDH (2009) 43 (2009), archived at http://perma.cc/7MDH-RW2Q.

214. Philip Leach et al., Can the European Court's Pilot Judgment Procedure Help Resolve Systemic Human Rights Violations? Burdov and the Failure to Implement Domestic Court Decisions in Russia, 10 Hum. RTS. L. REV. 346, 349 (2010).

215. Comm. of Ministers, Interim Resolution Execution of the Judgments of the European Court of Human Rights in 145 Cases Against the Russian Federation Relative to the Failure or Serious Delay in Abiding by Final Domestic Judicial Decisions Delivered against the State and its Entities as well as the Absence of an Effective Remedy, CM/ResDH (2009) 43 (2009), archived at http://perma.cc/QC2M-PUK2.

216. Comm. of Ministers, Non-Enforcement of Domestic Judicial Decisions in Russia: General Measures to Comply with the European Court's Judgments, supra note 207, ๆ 4.

217. Leach et al., supra note 214 , at 348. 
procedures to claim the necessary funds from the Ministry of Justice," further held up execution. ${ }^{218}$

The issue continued to attract attention from top authorities in the Russian government. In his 2007 report, Vladimir Lukin, the Commissioner for Human Rights of the Russian Federation, stressed that without unconditional execution of court decisions "the system of legal justice would transform to legal fiction." ${ }^{119}$ He criticized the widespread perception "not only in society but also in government bodies" that domestic judgments are merely "non-compulsory recommendations.",220 In our opinion, the report clearly noted awareness of the non-enforcement problem - extending even to some judgments of the Constitutional Courtamong authorities in Russia. Discussions took place in all federal circuits between December 2006 and March 2007 with representatives from both regional governments and the presidential administration, and these meetings developed the idea of "setting up a national filter mechanism that would allow for examination of Convention complaints at the domestic level." 221 The Commissioner emphasized that "joint efforts should be deployed with a view to eliminating the roots of the problem rather than simply reducing the number of complaints. $" 222$

Former Russian President Dmitry Medvedev also publicly emphasized the prevalence and endemic nature of non-enforcement. In an address to the Federal Assembly in November 2008, Medvedev specifically attributed the problem to the "lack of real accountability on the part of officials together with citizens themselves who neglect to execute court decisions" and called for the creation of a domestic mechanism to compensate citizens who had faced undue delays in execution of court decisions. ${ }^{223}$ A Moscow-based public interest lawyer, Olga Shepeleva, also pinpointed the lack of accountability as the main factor in an interview with British scholars Philip Leach, Helen Hardman, and Svetlana Stephenson. ${ }^{224}$ Shepeleva stressed that, although multiple institutions are responsible for guaranteeing enforcement, "in practice none of them takes the lead." 225 She further explained that the execution of judgments providing compensation

218. Leach et al., supra note 214 , at 348.

219. Vladimir Lukin, Doklad Upolnomochennoho po pravam cheloveka v Rossiyskoy Federatsii za 2007 god [Report of the Ombudsman for Human Rights in the Russian Federation for 2007], I 7.6, Rossiaskaya Gazeta, Mar. 14, 2008 archived at http://perma.cc/5ZJX-8WE2.

220. Id.; accord Burdov v. Russia (No. 2), 2009 Eur. Ct. H.R., archived at http://perma.cc/LK8A-ZHLR.

221. Burdov (No. 2) \25.

222. Id. $₫ 25$.

223. Dmitry Medvedev, President of Russia., Address to the Federal Assembly of the Russian Federation (Nov. 5, 2008), archived at http://perma.cc/8SDU-AQ2G.

224. Leach et al., supra note 214 , at 352.

225. Leach et al., supra note 214 , at 353. 
against public authorities are rarely prioritized by regional governments, as "the regional authorities lack the necessary funds to pay these sums," since "regional taxes are mostly channeled into the federal budget."226 While administrative confusion and uncertainty were clearly responsible for some of the problems in enforcing domestic decisions, the lack of personal liability also played a large role.

In 2008, two draft laws addressing non-enforcement were introduced in the Duma. The first, the Compensation Bill, sought to set up "a domestic legal remedy in respect of violations of the rights to judicial proceedings within a reasonable time and to the execution of an enforceable judicial decision within a reasonable time." 227 The bill provided that courts of general jurisdiction could consider these violations, outlined procedures for such a challenge, and specified that the Ministry of Finance would be the defendant. ${ }^{228}$ The second draft law amended other legislative acts, thereby establishing the Federal Treasury as responsible for providing compensation for damages found in such cases. ${ }^{229}$ The Russian Supreme Court, which decided to submit these bills to the Duma in September 2008, also described in an attached memorandum "the needs for additional budgetary allocations to ensure the implementation of the Compensation Bill," taking into account that the average amount awarded per case by the European Court of Human Rights was around $€ 3,050 .{ }^{230}$ When the court issued its judgment in the Burdov v. Russia (No. 2) case on January 15, 2009, these bills remained in the Duma. ${ }^{231}$ Notably, in February 2009 the Russian judge in the European Court of Human Rights, Anatoliy Kovler, emphasized the need for reform but criticized the bills as having been "cut to the roots" and no longer serving as effective solutions. ${ }^{232}$

\section{RUSSIA’s RESPONSE To The PILOT JUDGMENT}

The Russian response to the pilot judgment was relatively cooperative and proactive, although it did exceed one of the set deadlines. The judgment became final on May 4, 2009, after which Russia had six months to set up a new domestic remedy and twelve months to resolve all pending cases. ${ }^{233}$

226. Leach et al., supra note 214 , at 353.

227. Burdov v. Russia (No. 2), 2009 Eur. Ct. H.R. ๆ 35, archived at http://perma.cc/LK8A-ZHLR.

228. Id.

229. Id. $\llbracket 37$.

230. Id. $₫ 36$.

231. Id. ๆ $34-37$.

232. Leach et al., supra note 214 , at 355.

233. Execution of the Judgment of the European Court of Human Rights Burdov No. 2 Against the Russian Federation Regarding Failure or Serious Delay in Abiding by Final Domestic Judicial Decisions Delivered Against the State and its Entities as well as the Absence of an Effective Remedy, supra note 15. 
Although November 4, 2009 came and went with no legislative reform, in April of 2010 the Duma passed two new federal laws that entered into force on May 4, 2010, the day the court was set to resume consideration of the cases that had been adjourned for the previous year. ${ }^{234}$ Law FZ-68 "On Compensation for a Violation of the Right to a Trial within a Reasonable Time or the Right to the Enforcement of a Judgment within a Reasonable Time," known as the "Compensation Act," established the required domestic remedy, while FZ-69 amended other legislative acts. ${ }^{235}$ Following the pilot judgment, the Russian government also immediately began working to resolve the pending similar cases through ad hoc means, and "examined all applications within the time limits set by [the] Court." ${ }^{, 236}$ In total, the European Court of Human Rights struck out 785 applications that the Russian authorities successfully resolved domestically. ${ }^{237}$

The Committee of Ministers and the European Court of Human Rights both positively assessed the measures taken by Russia in response to the Burdov (No. 2) judgment. In September 2010, the court declared two new cases regarding non-enforcement to be inadmissible because of the new Compensation Act and referred them back to the domestic level. ${ }^{238}$ Perhaps most critical for the effectiveness of the new remedy, the Committee of Ministers confirmed that "appropriate funds were allocated to the federal budget, budgets of the subdivisions of the Russian Federation and local budgets" to guarantee the execution of decisions stemming from the Compensation Act. ${ }^{239}$ From May 2010 to June 2011, Russian courts considered 287 complaints about non-enforcement and granted compensation in 145 of the cases. ${ }^{240}$ Following a visit to Russia, Christos Pourgourides, the PACE rapporteur for the implementation of European Court of Human Rights judgments, acknowledged the efforts to tackle nonenforcement and other systemic issues offering that "[w]e can now see the light at the end of the tunnel.".241

234. Execution of the Judgment of the European Court of Human Rights Burdov No. 2 Against the Russian Federation Regarding Failure or Serious Delay in Abiding by Final Domestic Judicial Decisions Delivered Against the State and its Entities as well as the Absence of an Effective Remedy, supra note 15.

235. Comm. of Ministers, Appendix to Interim Resolution, Execution of the Judgment of the European Court of Human Rights Burdov No. 2 Against the Russian Federation Regarding Failure or Serious Delay in Abiding by Final Domestic Judicial Decisions Delivered Against the State and its Entities as well as the Absence of an Effective Remedy, CM/ResDH (2011) $293 \S 1$ (2011), archived at http://perma.cc/3QMJ-BA4W.

236. Id. $\S 2$.

237. Id. $\S 2$.

238. Id. $\S 3$.

239. Id. §1(b).

240. Id.

241. Parliamentary Assembly of the Council of Eur., Comm. on Legal Affairs AND HuMAN Rights (2010), archived at http://perma.cc/A4U2-ZEXQ. 


\section{UKRAINE AND RUSSIA: DIFFERENT APPROACHES TO ENFORCEMENT OF COURT DECISIONS}

Given the systemic nature of non-enforcement, why was Russia able to craft, pass, and implement reform following a pilot judgment, while Ukraine was not? The answer lies in the specifics of the problem, history of cooperation with the Council of Europe, and internal politics of both countries. In Russia, as described above, non-enforcement was largely an administrative issue, with multiple agencies theoretically responsible for enforcement, compounded by a lack of measures to ensure accountability. In Ukraine, while administrative issues are present, both the existing moratoriums on sale of state assets and energy-related companies and the social benefits are directly tied to the financial and political interests of politicians. Moreover, Russia had been working for years, in cooperation with the Committee of Ministers, to address the underlying issues. Unlike Ukraine, which reported the creation of a national plan and draft laws but did not actually engage in any legislative reform prior to the pilot judgment, Russia passed three major pieces of legislation between 2005 and 2007 aimed at improving enforcement. ${ }^{242}$ When it came time to respond to the pilot judgment, the Russian authorities had a history of substantive debate and consideration of the underlying issues in the judicial, presidential, and legislative spheres, which may have made it easier to craft and set up a concrete mechanism. Additionally, the Russian government also did not experience a major power shake-up, while the 2010 election of Viktor Yanukovych and the formation of the new Cabinet led by Mykola Azarov in Ukraine led to scrapping past efforts at reform. ${ }^{243}$

Reform may also have been easier to achieve in Russia due to the country's finances. In the 2007 memorandum, the Russian authorities themselves noted that the issue was not financial but organizational. ${ }^{244}$ The Committee of Ministers, in their 2011 evaluation of the pilot judgment, noted that Russia had allocated the necessary budgetary resources to enforce any judgments under the Compensation Act. ${ }^{245}$ In contrast, nonenforcement in Ukraine is tied to budget shortages, which are reflected every year in the large percentage of social benefits which go unpaid and in the debate over granting the executive branch the ability to adjust the levels

242. See supra Part $\mathrm{X}$ for a discussion of the 2005 and 2007 reforms to the Budgetary Code and the 2007 Federal Law on Enforcement Proceedings.

243. See Law No. 1861-VI, supra note 121.

244. Non-Enforcement of Domestic Judicial Decisions in Russia: General Measures to Comply with the European Court's Judgments, supra note 207, 94.

245. Execution of the Judgment of the European Court of Human Rights Burdov No. 2 Against the Russian Federation Regarding Failure or Serious Delay in Abiding by Final Domestic Judicial Decisions Delivered Against the State and its Entities as well as the Absence of an Effective Remedy, supra note 15. 
of benefits in proportion to the budget. ${ }^{246}$ Nazar Kulchytsky, the Government Agent of Ukraine to the European Court of Human Rights, emphasized the monetary factor, arguing that "Russians didn't resolve this problem, they just have enough money to pay compensation to everyone whose right for execution in a reasonable time was violated." ${ }^{247}$ He posited that the Russian remedy is "going to work for a few years, but when a lot of people will find out about this mechanism, and when they will see that it is effective, the amount of those compensation [sic] will be much larger than the amount of the debt itself," and "that it's not possible to make things in such a way for a long time." 248 Kulchytsky emphasized with fewer available funds, such a solution is not an option for Ukraine. ${ }^{249}$

Lastly, another factor in Russia's response is the political context of Russia's relationship with the European Court of Human Rights. While responding to the Burdov (No. 2) judgment may constitute a success, Russia has long had a contentious relationship with the court. The court has ruled on hundreds of cases from Chechnya and neighboring North Caucasus republics concerning violations of article 2, the right to life, or article 3, freedom from torture. ${ }^{250}$ These cases remain partially unenforced, as Russia has resisted any general measures related to the Chechen cases, which have been the subject of much condemnation by the court. ${ }^{251}$ Antoine Buyse, a Dutch scholar of the court, explained the court's application of the pilot judgment procedure thusly: "[T]o put it mildly, it is no secret that Russia is not very happy with the Court's judgments in the many Chechen cases. No surprise then that the Court has found a (somewhat) less sensitive area to find a systemic problem."252 Responding to the pilot judgment cooperatively, substantively, and relatively on time may have been a means of creating some political goodwill at the Council of Europe towards Russia, in the context of years of directed criticism.

\section{IMPLICATIONS FOR UKRAINE AND THE EUROPEAN HUMAN RIGHTS REGIME}

The Ukrainian and Russian responses to the pilot judgments and to the issue of non-enforcement more generally have implications for both

246. See supra Part VI.

247. Interview by Carolyn Forstein with Nazar Kulchytsky, supra note 103.

248. Interview by Carolyn Forstein with Nazar Kulchytsky, supra note 103.

249. Interview by Carolyn Forstein with Nazar Kulchytsky, supra note 103.

250. European Court of Human Rights, Country Factsheet, Russia 9, archived at http://perma.cc/5LQU-UCSM.

251. Id.; Case of Aslakhanova and Others v. Russia, 2013 Eur. Ct. H.R., archived at http://perma.cc/ML5B-E49C.

252. Antoine Buyse, Pilot Judgment on Russian Non-Enforcement, ECHR BLOG (Jan. 21, 2009, 11:00 AM), http://echrblog.blogspot.com/2009/01/pilot-judgment-on-russiannon.html, archived at http://perma.cc/Q3Q3-8QCE. 
future domestic reforms and the European system of human rights protection. Ukraine's failure to respond to the Ivanov judgment within the time period demonstrates a key weakness of the pilot judgment procedure: it is entirely predicated on the national government in question implementing reform. Ukraine is the first country to fail to respond and has seemingly faced no tangible consequences. Volodymyr Yavorsky recounted how even the Council of Europe "was simply surprised" at Ukraine's response, particularly as "even Russia did something." 253 Additionally, the hundreds of applicants whose cases were frozen for the period of the pilot judgment and were not resolved domestically were effectively denied an opportunity to seek justice for over two years.

At the same time, while Ukraine's response was scant, the pilot judgment pushed the government to consider non-enforcement in a more serious light than it had previously. This sentiment has been echoed by multiple Ukrainian officials. Kulchytsky emphasized the importance of international pressure, describing the pilot judgment as "the only possibility" for compelling "our authorities to make some changes." "254 The European Court of Human Rights first recognized that non-enforcement was an issue in Ukraine over eight years ago, but only after the pilot judgment did the government "finally start asking [the Ministry of Justice] what the problem is" and what should be done "to change the situation." 255 Ivanna Ilchenko went further, describing the "incredible impact" of the pilot judgment: for over 2000 cases, the government is responsible for paying not only "the amount which was owed by the judgment which was not executed, but also the amount of penalty from the government for the nonexecution period." ${ }^{, 256}$ While far short of European Court of Human Rights's goal, the Ukrainian government's settlement of over 1000 of the pending cases, and its obligation to compensate applicants not only for the original debt but for the delay in enforcement is a concrete result. While these statements do not mitigate the extent to which Ukraine failed to meet the obligations set forth in the Ivanov judgment, they emphasize the level of attention that the decision garnered among the legal professionals in the government.

The Ukrainian and Russian responses to the pilot judgments also highlight the continued importance of the European Court of Human Rights as a guarantor of human rights, particularly in the countries which produce the most applications. This is particularly relevant given the ongoing debate about the future of the court. Three high-level meetings of the past few years, at Interlaken in 2010, Izmir in 2011, and most recently Brighton in

253. Interview by Carolyn Forstein with Volodymyr Yavorsky, supra note 147.

254. Interview by Carolyn Forstein with Nazar Kulchytsky, supra note 103.

255. Interview by Carolyn Forstein with Nazar Kulchytsky, supra note 103 (alteration added).

256. Interview by Carolyn Forstein with Ivanna Ilchenko, supra note 151. 
2012, have focused attention on the overwhelming backlog of cases at the court, seeking ways to decrease the caseload and improve the effectiveness of the court. ${ }^{257}$ The 2012 Brighton Declaration included several proposals for reducing the current and future caseload, and called on the Committee of Ministers to "ensure that States Parties quickly and effectively implement pilot judgments," and on states to fulfill their Convention obligations. $^{258}$

While reducing the court's caseload is clearly a necessary step towards improving the efficiency and functionality of the court, it cannot be achieved at the cost of individuals' human rights. The Ivanov and Burdov judgments demonstrate the need for the court to continue to consider repetitive article 6 violations, and to continue to attempt to find creative solutions to systemic problems such as the pilot judgment procedure. Although the pilot judgment mechanism did not work in full in Ukraine, it has had a greater impact - as measured by the 1000 plus cases resolved domestically - than any other effort to address non-enforcement since Ukraine joined the Council of Europe. Though such cases are time consuming and repetitive, the European Court of Human Rights stands as a last resort for the majority of Ukrainians who take a case to court and find that their domestic decisions go unenforced. As the outgoing Commissioner for Human Rights for the Council of Europe, Thomas Hammarberg, emphasized in a speech at the opening of the 2012 judicial year in Strasbourg, "the problem is not that people complain, but that many of them have reasons to do so." 259 The failure to enforce judgments is directly tied to quality of life and to the rule of law, and though it plays out in small numbers and individual experiences, it adds up to a major human rights shortcoming, which cannot be abandoned.

Given the significance of the issue, one takeaway from the Ukrainian case may be the need for the Council of Europe to apply increased pressure on recalcitrant national governments. The Council of Europe has a number of measures at its disposal, which it can use on states which are not living up to their obligations, including suspending membership in the organization or applying sanctions on a state. ${ }^{260}$ Nazar Kulchytsky criticized the Committee of Ministers for being "afraid to use strong phrases,"

257. See the reports of the 2010, 2011, and 2012 Interlaken, Izmir, and Brighton conferences, supra note 27.

258. Council of Eur. High Level Conference on the Future of the European Court of Human Rights, Brighton Declaration, I 27 (Apr. 19-20, 2012), available at http://hub.coe.int/20120419-brighton-declaration.

259. Thomas Hammarberg, Council of Eur. Comm'r for Human Rights, The Court of Human Rights Versus the 'Court of Public Opinion,' CommDH/Speech (2012) 1 (Jan. 27, 2012), archived at http://perma.cc/6PWL-Q89A.

260. Statute of the Council of Europe, May 5, 1948, arts. 3, 8, archived at http://perma.cc/EJA6-JUHT; Pourgourides, 7th Report, supra note 20, $₫ 213$. 
explaining that even "when we are telling them it's not going to work in Ukraine in such a way, we need strong formulations, the Committee of Ministers also very often is not ready to take such strong steps."261

The criticism and public spotlight which has been focused on the Yanukovych administration for the Tymoshenko and Lutsenko trials should also be applied to non-enforcement, which is just as much a stumbling block to rule of law as is a biased judiciary. The government's failure to respond to Ivanov should not be allowed to fly under the radar of the international community or dismissed by domestic proponents of rule of law, particularly as Ukraine seeks closer economic integration with Europe. As Europe considers the future of the Council of Europe and of international human rights protection, it should take into account not only its ability to serve as a guardian of human rights and a monitor of violations, but also its role as an active enforcer.

\footnotetext{
261. Interview by Carolyn Forstein with Nazar Kulchytsky, supra note 103.
} 
